\title{
The Genes of Capsicum
}

\author{
Deyuan Wang \\ Vegetable Institute, Guangdong Academy of Agricultural Sciences, \\ Guangzhou, Guangdong, China 510640
}

\author{
Paul W. Bosland ${ }^{1}$ \\ Department of Plant and Environmental Sciences, New Mexico State \\ University, Las Cruces, NM 88003
}

Additional index words. aji, chile pepper, genetics, vegetable breeding

\begin{abstract}
Pepper (Capsicum spp.) is one of the most cultivated vegetable and spice crops in the world. Capsicum genetics have been extensively studied, but the most recent Capsicum gene list was published more than a decade ago. Since then, new genes have been described. This updated gene list provides detailed descriptions of genes, including the genes' characteristics, the genetic background of the mutants/lines, action mechanisms of genes, gene interactions, molecular markers, and chromosome localization when available. This new list includes 292 genes for morphological traits; physiological traits; sterility; and resistance to diseases, nematodes, and herbicides, which includes the 92 genes that have not been previously described.
\end{abstract}

Pepper (Capsicum spp.) is one of the most cultivated vegetable and spice crops worldwide, and plays an important role as a constituent in many of the world food industries (Bosland and Votava, 2000). Peppers were one of the first plants to be domesticated and cultivated in the western hemisphere. The small-fruited wild forms of peppers - chiltepins - are still found growing wild in Arizona and Texas in the United States. World pepper production in 2004 reached 1.65 million ha with more than 24 million metric tons harvested (FAO, 2005). China is the world's largest producer, with more than $33 \%$ of the total production area and nearly $50 \%$ of total world production (FAO, 2005).

Capsicum is native to the tropical and subtropical Americas and may comprise up to 30 species, among which the five major cultivated species are $C$. annuum L., $C$. frutescens L., C. chinense Jacq., C. baccatum L., and C. pubescens Ruiz and Pavon (Bosland, 1992). Worldwide, C. annuum is the most cultivated and economically important species, and includes both sweet and hot fruits in myriad shapes and sizes.

Most Capsicum species are diploid $(2 n=$ $2 x=24$ ), but there are a few species for which the genome is $2 n=2 x=32$. Capsicum has a large genome, with the $2 \mathrm{C}$ DNA content ranging from $7.65 \mathrm{pg} /$ nucleus in $C$. annuum to $9.72 \mathrm{pg} /$ nucleus in $C$. pubescens, and with

\footnotetext{
Received for publication 24 Feb. 2006. Accepted for publication 27 Apr. 2006. The authors gratefully acknowledge the Chinese Scholarship Committee for providing financial support to D. Wang as a visiting scholar. They thank and express their appreciation to Emily Bosland and the anonymous reviewers for their suggestions to improve the manuscript. A contribution of the New Mexico Agr. Expt. Sta., New Mexico State Univ., Las Cruces, N.M.

${ }^{1}$ To whom reprint requests should be addressed. e-mail pbosland@nmsu.edu.
}

a general mean of $8.42 \mathrm{pg} /$ nucleus (Belletti et al., 1998). These values correspond to the 1c genome size of 3.691 (C. апnuum), 4.690 (C. pubescens), and 4.063 (general mean) Mbp. C. annuum genome is about three to four times the size of the tomato (Solanum lycopersicum L.) genome (Arumuganathan and Earle, 1991).

Capsicum genes have been studied since Webber, in 1912, investigated the inheritance of several traits (cited in Boswell, 1937). Other early contributions to Capsicum genetics were made by Atkins and Sherrard (1915) of England, Deshpande (1933) of India, Ikeno $(1913,1917)$ of Japan, and Halsted (1918) and Dale $(1929,1931)$ of the United States (all cited in Boswell, 1937). In 1933, Matsuura summarized pepper genetics, from 1910 to 1929 , that consisted of 12 characters without designating any gene symbols (cited in Boswell, 1937). Boswell (1937) reviewed the inheritance of 16 characters in pepper, of which seven gene symbols were recorded for seven different traits (purple foliage and stem color, intense purple foliage and stem color, red mature fruit color, blunt fruit apex, bulged fruit base, pendent fruit position, and nonclasping fruit calyx). After Boswell's work, inheritance studies in pepper gained more interest and included more important traits associated with greater importance of pepper production worldwide, as well as more induced or spontaneous mutants being obtained.

From the late 1980 s, more efforts to tag the identified genes with molecular markers, and to clone and characterize the genes were undertaken (Lefebvre et al., 1995). Paran and colleagues (2004) used data from six individual maps from the United States, Israel, and France to construct an integrated genetic map of Capsicum including six distinct progenies and 2262 genetic markers covering $1832 \mathrm{cM}$. Many markers and quantitative trait loci (QTLs) are linked with important traits, and the pun-1 gene, which causes heat in the fruit, was successfully cloned (Stewart et al., 2005).

Lippert and associates (1965) compiled the first Capsicum gene list containing 50 genes, and proposed the basic rules for Capsicum gene nomenclature and symbolism according to the Report of the Committee on Genetic Symbols and Nomenclature. Later, Lippert and associates (1966) increased the list to 75 genes (cited in Daskalov and Poulos, 1994). Daskalov (1973) presented, in Bulgarian, a gene list with nearly 90 genes. For the benefit of pepper breeders, Greenleaf (1986) produced a gene list considered important to pepper breeding that was adapted from the gene lists of Lippert and associates $(1965,1966)$, and proposed several new gene symbols. The Capsicum and Eggplant Newsletter Editorial Board (CENL) (1994) proposed the rules for gene nomenclature of Capsicum to assist in standardizing and articulating the gene symbols. Based on these rules, Daskalov and Poulos (1994) compiled a list of the known genes, reassigned several gene symbols, and standardized other confusing symbols.

The gene list updated here has been modified and updated from previous lists, especially the gene list of Daskalov and Poulos (1994). The current gene list contains detailed descriptions of the gene mutants and gene lines as well as the genetic background (cultivars or accessions, and species). If known, we have also added the acting mechanisms and characteristics of genes and gene interactions. In addition, molecular markers and the chromosome localization of genes have been added.

In addition to the genes listed by Daskalov and Poulos (1994), 92 new genes have been added to this gene list. The gene symbols proposed are in accordance to the rules for gene nomenclature of Capsicum for those characters that have been examined for inheritance (CENL, 1994). An attempt was made to correct errors in the gene symbols or descriptions from previous lists. This gene list (Table 1) presents the 292 known genes of Capsicum, including morphological traits, physiological traits, sterility, and resistance to diseases, nematodes, and herbicides.

\section{Gene Nomenclature for Capsicum}

The basic rules for Capsicum gene nomenclature have been proposed by Lippert and associates (1965), and adopted by Daskalov (1973), Csillery (1980a, 1983), Greenleaf (1986), Daskalov and Poulos (1994), and then updated by the CENL Committee for Capsicum Gene Nomenclature (1994). In brief, the rules for assigning gene symbols adopted from others are that genes are symbolized by a maximum of three italicized Roman letters. The first letter of the symbol should be the same as that for the gene name, which should describe a characteristic feature of the mutant type in a minimum of adjectives or nouns in English or Latin. When the mutant is dominant, the first letter of the symbol is capitalized; if the mutant is 


\begin{tabular}{llcc}
\hline Preferred symbol & Synonym & Character & References \\
\hline$A$ & $F$ & $\begin{array}{c}\text { Anthocyanin; the incompletely dominant gene for } \\
\text { anthocyanin color in the foliage, flower, and }\end{array}$ & $\begin{array}{c}\text { Lippert et al., 1965; Odland, 1960; } \\
\text { Peterson, 1959 }\end{array}$ \\
& immature fruit & Anthocyanin-less; prevents purple color on the stem, \\
fl-1 to al-8 & fruits, and in plants; nodes, green; anthers, yellow; & Cook, 1961b; Csillery, 1980a, \\
& only al5 shows a slight purplish marking along the & 1983, 1984; Daskalov, 1973a, b; \\
& lines of dehiscence; lack of purple spots on & Daskalov and Poulos, 1994; \\
& Greenleaf, 1986; Odland, 1960
\end{tabular}

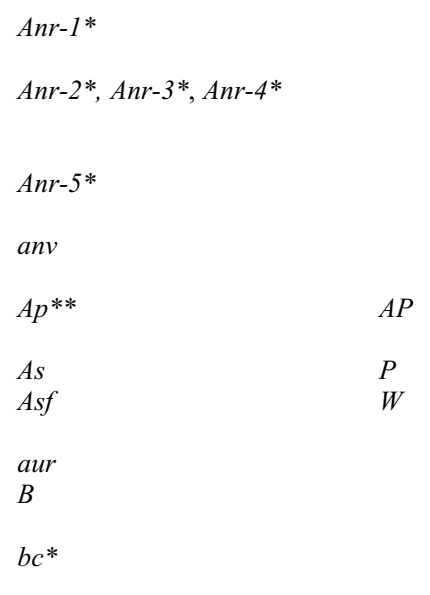

$b l$

$b r l$

$B s-1$

$B s-2$

$B s-3$

$B s-4 *$

$b s-5^{*}, b s-6^{*}$

$b v$

mutant-2

$B z t$

$c-1$

$c-2$

$c a$

call

ce immature fruits; in some genotypes, and especially in cold and rainy weather, purple spots on the nodes and immature fruits may be observed; epistatic to $A$, $A s$, and Asf; nonallelic; al6 and al7 found in $C$.

chinense, al8 found in C. chacoense; linkage found between al 2 and mos 2

Anthracnose resistance; resistance of C. annuum cv. Chungryong to $C$. dematium

Resistance to C. gloeosporioides in C. annuum, Anr2 in 'BGH3077'; two genes Anr3 and Anr4 in 'BGH2850' and 'BGH5085'

Anthracnose resistance; resistance to $C$. capsici in the line '83-168'

Angustifolia variegada; elliptical cotyledons, long and narrow leaves

The pointed shape of the fruit apex; dominant to the indented shape

Anthocyanin on style; purple in the absence of $A$ or Asf

Anthocyanin on style and filament; purple in the absence of $A$.

Aurea; golden cotyledons and leaves

Beta-carotene; high beta-carotene content in mature fruits; interacts with $t$

Beta-carotene; high beta-carotene content conferred by preventing hydroxylation of beta-carotene to beta-cryptoxanthin; mutant from 'Pasardzhishka Kapia'

Branchless; plants grow normally to the stage of first stem bifurcation, then stem development stops; found in PI 169113

Braquitica latifoliata; shortened stem internodes; leaf blades wide, large, round, and dark green with short, thickened petioles

Bacterial spot resistance; hypersensitive resistance in PI 163192 to race 2 of $X$. campestris $p v$. vesicatoria Bacterial spot resistance; hypersensitive resistance in PI 260435 to both race 1 and race 2 of $X$. campestris pv. Vesicatoria

Bacterial spot resistance; hypersensitive resistance in PI 271322 to race 1 of $X$. campestris $p v$. vesicatoria Bacterial spot resistance: hypersensitive resistance in PI 235047(C. pubescens) to race 6 of $X$. campestris pv. vesicatori.

Bacterial spot resistance; nonhypersensitive resistance in ECW-12346 to race 6 of $X$. campestris pv. vesicatoria

Bushy variegated; plants with creamy white apical leaves spotted with small green areas; extensive lateral shoot development provides a bushy appearance

Bentazon tolerance; confers a high level of tolerance to herbicide bentazon in C. annuum cv. 'Santaka'; modifying genes may affect the Bzt gene in 'Bohemian Chilli'

Carotenoid pigment inhibitors; reduce $10 \%$ in red color of mature fruits; $c 1$ and $c 2$ reduced pigmentation of $y^{+}$and $y$ by the inhibition of betacarotene

Carotenoid pigment inhibitors; much stronger red color reduction than $c 1$

Canoe; margins of cotyledons and leaves are rolled upward by hyponasty; weak and tumbling stem

Callus proliferations; tiny wartlike structures scattered on cotyledon, stem, and leaf; more pronounced on the abaxial surface

Calyx enclosed; calyx-enclosed fruit base; loci ce and $f b$ are linked at $4.7 \mathrm{cM}$
Park et al., 1992

Fernandes and Ribeiro, 1998

Lin et al., 2002

Daskalov and Poulos, 1994

Ishikawa et al., 1998

Lippert et al., 1965

Lippert et al., 1965; Odland, 1960

Daskalov and Poulos, 1994

Lippert et al., 1965

Chalukova et al., 1993; Daskalov et al., 1995

Bergh and Lippert, 1964

Daskalov and Poulos, 1994

Cook and Stall, 1963

Hibberd et al., 1987

Hibberd et al., 1987

Sahin and Miller, 1997, 1998

Jones et al., 2002

Cook, 1962; Lippert et al., 1964

Fery and Harrison, 1990; Wolff et al., 1992

Hernandez and Smith, 1985; Lippert et al., 1965

Hernandez and Smith, 1985;

Lippert et al., 1965

Csillery, 1980a

Csillery, 1983

Miller and Fineman, 1938 
Table 1. (Continued) The genes of Capsicum.

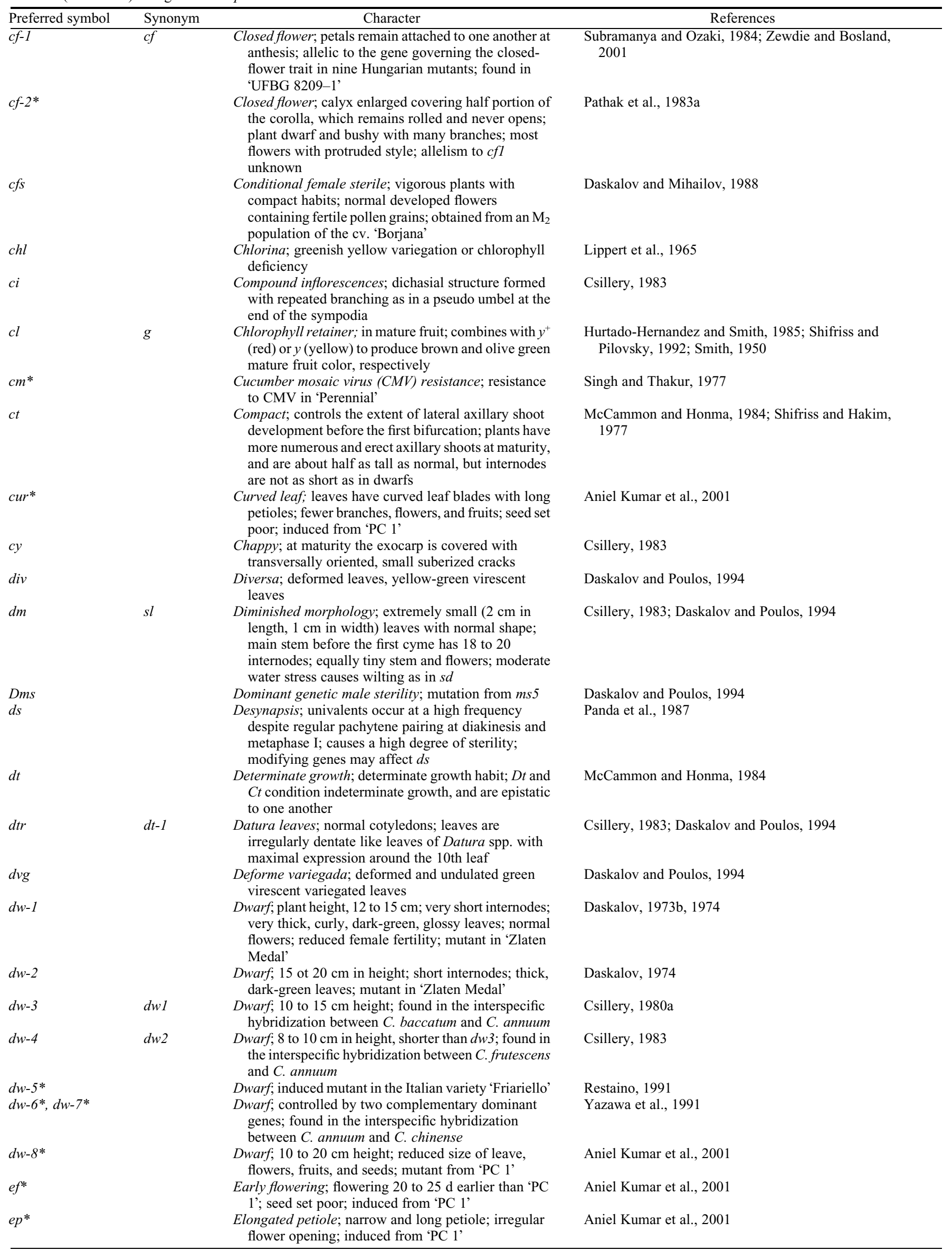


Table 1. (Continued) The genes of Capsicum.

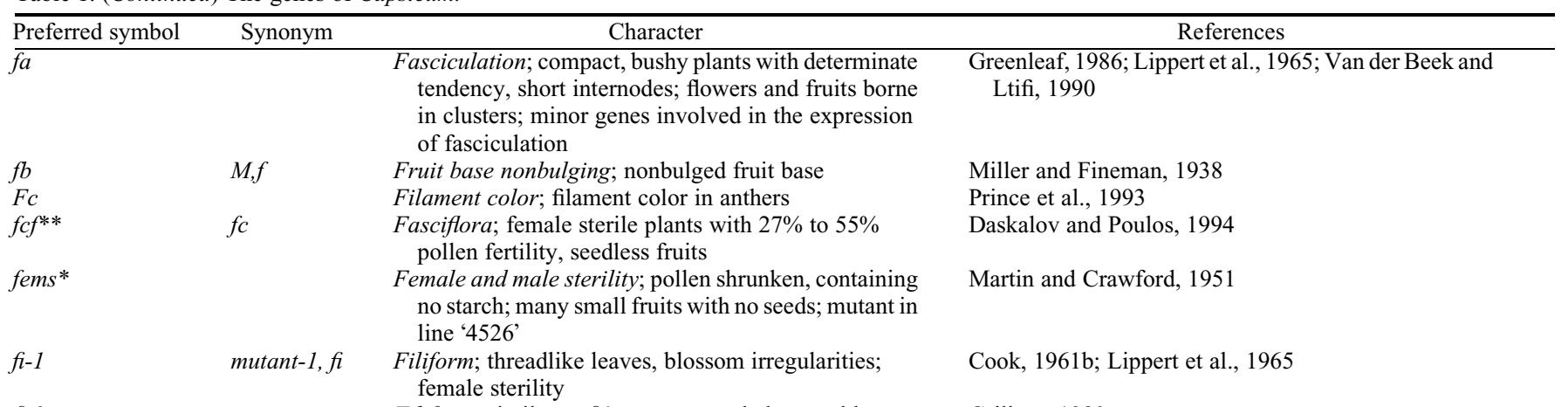

fi-2 Filiform; similar to fil; narrow cotyledons and leaves (3-4 mm); threadlike petals; carpels usually not fused to pistil except in particularly small fruited varietal background; incomplete female sterile

Folded leaf; leaves folded upward, giving boat-shaped appearance; prominent in seedlings; partially fertile; induced from 'PC 1'

$f l c$

Flaccid; cotyledons and leaves exhibit flaccid condition; the mutant has a normal leaf phenotype, but under typical field and greenhouse conditions it becomes flaccid; induced mutant from 'Keystone Resistant Giant No. 3'

$f l *$

Flv

Flowerless plant; profuse vegetative growth, induced from 'PC 1'

Flavi; yellow-green leaves, shorter and less vigorous plants

fms

Functional male sterility; degenerated corolla; shriveling stamens develop incomplete anther and stigma; anthers closed by longer calyxes; mutant from 'Fudijian'

$f r$
$f S$

Frilly; leaf margins are marked by undulation

Female sterile; complete female sterility with no other primary phenotypic effects; mature plants with a twiggy, multiflorous periphery; mutant from PI 159276

$f v$

Fan vein; veins of true leaves are branching like a fan; the leaf blade is often dissected, segments curled like tendrils, corolla, and other parts of the flower are irregularly reduced, but fruits may develop; found in C. chacoense

$g d$

Glossy diminutive; small leaves with an unusual, pale glossy appearance; plants vary from tiny to as large as one-sixth of the normal plant size; mutant from PI 159226

General defense system; provides resistance to Xanthomonas campestris pv. vesicatoria in PI 163192; promotes cell growth and cell wall thickening

Graft incompatible; manifests when grafted to other Solanaceae

$H$

ht

Hairy or pubescent leaf surface; dominant gene; $H_{-}$is epistatic to $S m_{-}$whereas smsm is epistatic to $h h$.

Hungarian tricolor; the basal one-fifth part of the fruit less pigmented, like $s w$ before maturity, whereas more or less dark-green on top four-fifths portion; at full maturity a red-white-green fruit color results from the top to the calyx

im

Intermediate; purple color at intermediate maturity in originally nonpurple immature fruit; relation to $A$ unknown.

$k$

$L^{1} \quad L^{i}, l^{i}$

Easy pedicle detachment from node; related to flower and young fruit abscission

Localization; localization of $\mathrm{P}_{0}$ strain of tobacco mosaic virus (TMV) in 'Bruinsma Wonder' and 'Verbeterde glas'

Localization; localization of TMV resistance at high temperature; 'C' for 'Criollo de Moralos-334'; allelic at $L$ locus

$L^{2} \quad L$

Localization; localization of both $\mathrm{P}_{0}$ and $\mathrm{P}_{1}$ strains of TMV in C. frutescens cv. Tabasco

Csillery, 1980a

Aniel Kumar et al., 2001

Bosland, 2002

Aniel Kumar et al., 2001

Daskalov and Poulos, 1994

Yuan and Li, 2000

Csillery, 1980a

Bergh and Lippert, 1964

Csillery, 1980a

Bergh and Lippert, 1964

Csillery et al., 2004; Szarka and Csillery, 1995

Lippert et al., 1965

Holmes, 1934; Shuh and Fontenot, 1990

Csillery, 1983

Lippert et al., 1965

Uzo, 1984

Boukema et al., 1980b; Holmes, 1934, 1937

Daubeze et al., 1990

Boukema, 1980; Holmes, 1934, 1937

(Continued on next page) 
Table 1. (Continued) The genes of Capsicum.

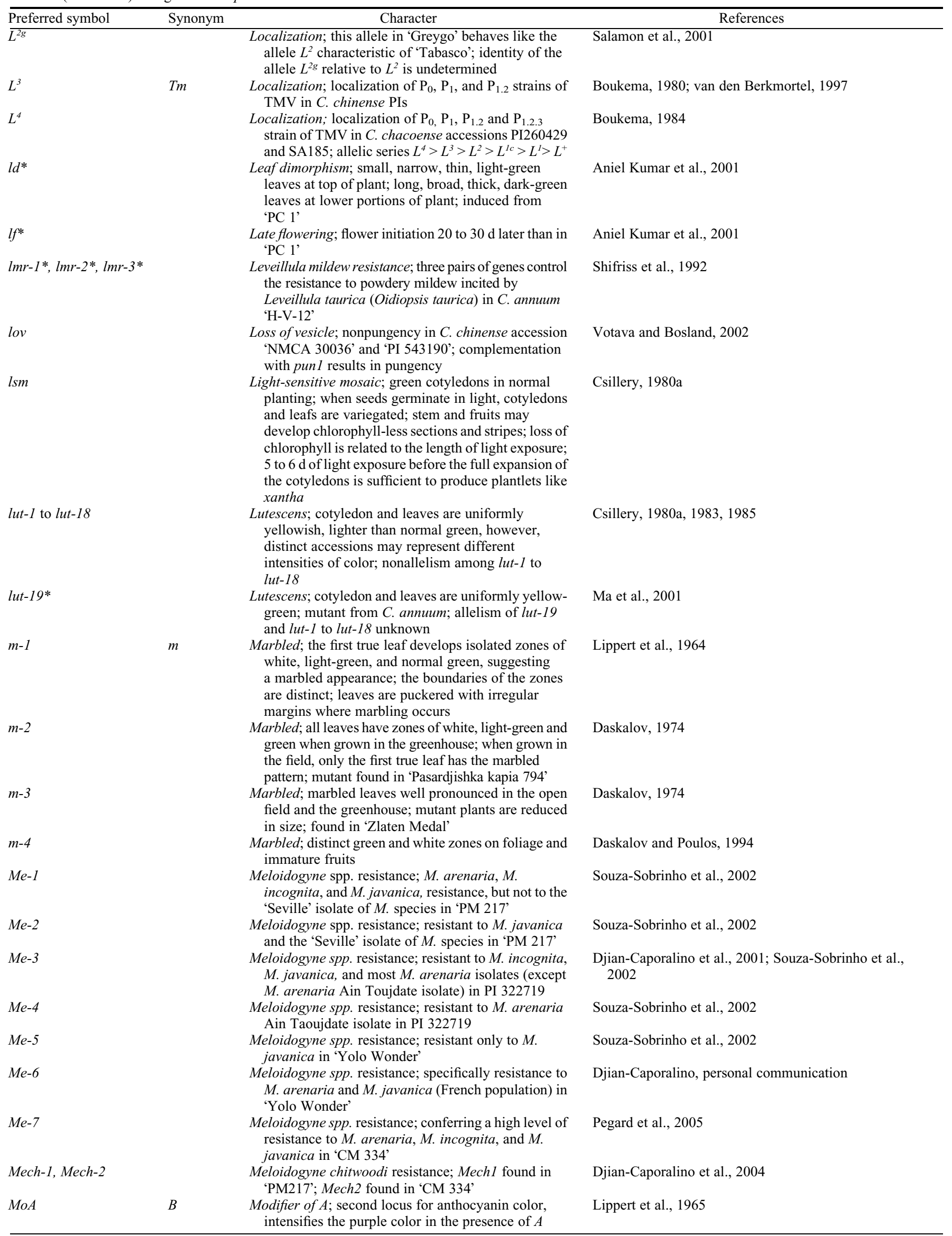

(Continued on next page) 
Table 1. (Continued) The genes of Capsicum.

\begin{tabular}{|c|c|c|c|}
\hline Preferred symbol & Synonym & Character & References \\
\hline$M f-1, M f-2, M f-3$ & $M 1, M 2, M 3$ & $\begin{array}{l}\text { Multiple flowers per node; controls multiple flower } \\
\text { expression; recessive homozygosity at any two loci } \\
\text { is epistatic to the dominant allele present at the third } \\
\text { locus }\end{array}$ & Daskalov and Poulos, 1994; Shuh and Fontenot, 1990 \\
\hline$m s-2$ & & $\begin{array}{l}\text { Genic male sterility; shrunken anthers that release } \\
\text { numerous, aborted pollen grains; mutant from } \\
\text { 'California Wonder' }\end{array}$ & Shifriss and Rylski, 1972 \\
\hline$m s-3$ & & $\begin{array}{l}\text { Genic male sterility; shrunken anthers, in some cases } \\
\text { only a very small amount of fertile and sterile } \\
\text { pollens are formed; irradiation induced mutant from } \\
\text { 'Pasardjishka Kapia 794' }\end{array}$ & Daskalov, 1968 \\
\hline$m s-5$ & & $\begin{array}{l}\text { Cytoplasm male sterility; anthers are very severely } \\
\text { reduced, contain no pollen grains in field; under } \\
\text { greenhouse conditions certain plants may produce } \\
\text { a small amount of fertile pollen grains; irradiation } \\
\text { induced mutant from 'Kalinkov } 800 / 7 \text { ' }\end{array}$ & Daskalov, 1974 \\
\hline$m s-6, m s-7, m s-8$ & & $\begin{array}{l}\text { Genic male sterility; shrunken anthers with reduced } \\
\text { anther sizes; sometimes only a very small amount of } \\
\text { fertile pollens are formed; nonallelic among } m s-1 \text { to } \\
m s-8 \text {; irradiation induced mutant from 'Zlaten } \\
\text { Medal' }\end{array}$ & Daskalov, 1973b \\
\hline$m s-9$ & $m r 9$ & $\begin{array}{l}\text { Genic male sterility; } \gamma \text {-irradiation induced male sterile } \\
\text { mutants }\end{array}$ & Daskalov and Poulos, 1994; Greenleaf, 1986 \\
\hline$m s-13 *$ & $m s$ & $\begin{array}{l}\text { Genic male sterility; complete pollen sterility; the } \\
\text { postmeiotic breakdown of microspores; mutant } \\
\text { from 'CA452-1' }\end{array}$ & Meshram and Narkhede, 1982 \\
\hline$m s-14^{*}$ & & $\begin{array}{l}\text { Genic male sterility; androecium transformed into } \\
\text { petaloid structures; mutant from 'Kalyanpur } \\
\text { selection' }\end{array}$ & Pathak et al., 1983b \\
\hline$m s-15^{*}$ & $m s$ & $\begin{array}{l}\text { Genic male sterility; anthers are dark blue, and reduced } \\
50 \% \text {; postmeiotic breakdown of the microspore } \\
\text { during the formation of male gametes; mutant from } \\
\text { 'CA-960' }\end{array}$ & Meshram et al., 1992 \\
\hline$m s c-1^{*}$ & & $\begin{array}{l}\text { Genic male sterility; spontaneous mutant found in } \\
\text { China; allelism with } m s-1 \text { to } m s-15 \text {, and } m s k \\
\text { unknown }\end{array}$ & Yang, 1981; Yang et al., 1994 \\
\hline$m s c-2^{*}$ & & $\begin{array}{l}\text { Genic male sterility; spontaneous mutant found in } \\
\text { China from 'Ying Ge Bai Er'; allelism with } m s-1 \text { to } \\
m s-15, m s c-1 \text { and } m s k \text { unknown }\end{array}$ & Fan and Guo, 1994; Fan et al., 2004 \\
\hline msk & & Genic male sterility; spontaneous mutant in Korea & Shifriss, 1973 \\
\hline$N$ & & $\begin{array}{l}\text { Root-knot nematode resistance; resistance to } M . \\
\text { incognita in 'Santaka' }\end{array}$ & Hare, 1957 \\
\hline$n f$ & & $\begin{array}{l}\text { Nonflowering; no flowering throughout the growing } \\
\text { season }\end{array}$ & Pathak et al., 1985 \\
\hline$n l^{*}$ & & $\begin{array}{l}\text { Narrow leaf; narrow leaves; reduced branches, flowers, } \\
\text { and fruits; induced from 'PC 1' }\end{array}$ & Aniel Kumar et al., 2001 \\
\hline$O$ & & $\begin{array}{l}\text { Oblate fruit shape; fruit shape independent of fruit } \\
\text { size; modifiers also affect fruit shape } A, O \text {, and } s w 1 \\
\text { are linked, the linear order and the map distances are } \\
A-6.5-O-18.8-s w_{1}\end{array}$ & Peterson, 1959 \\
\hline
\end{tabular}

(Continued on next page) 
Table 1. (Continued) The genes of Capsicum.

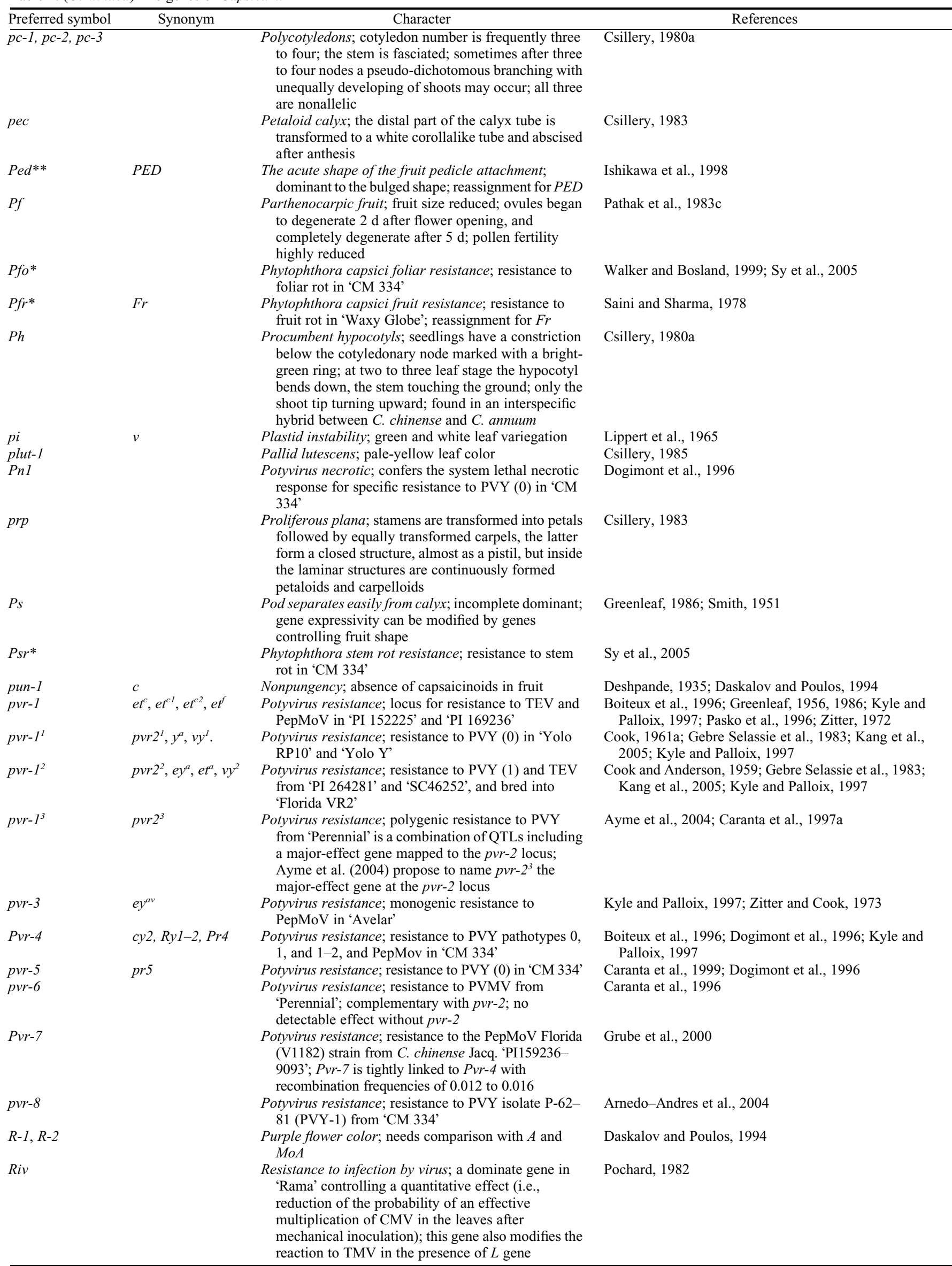


Table 1. (Continued) The genes of Capsicum.

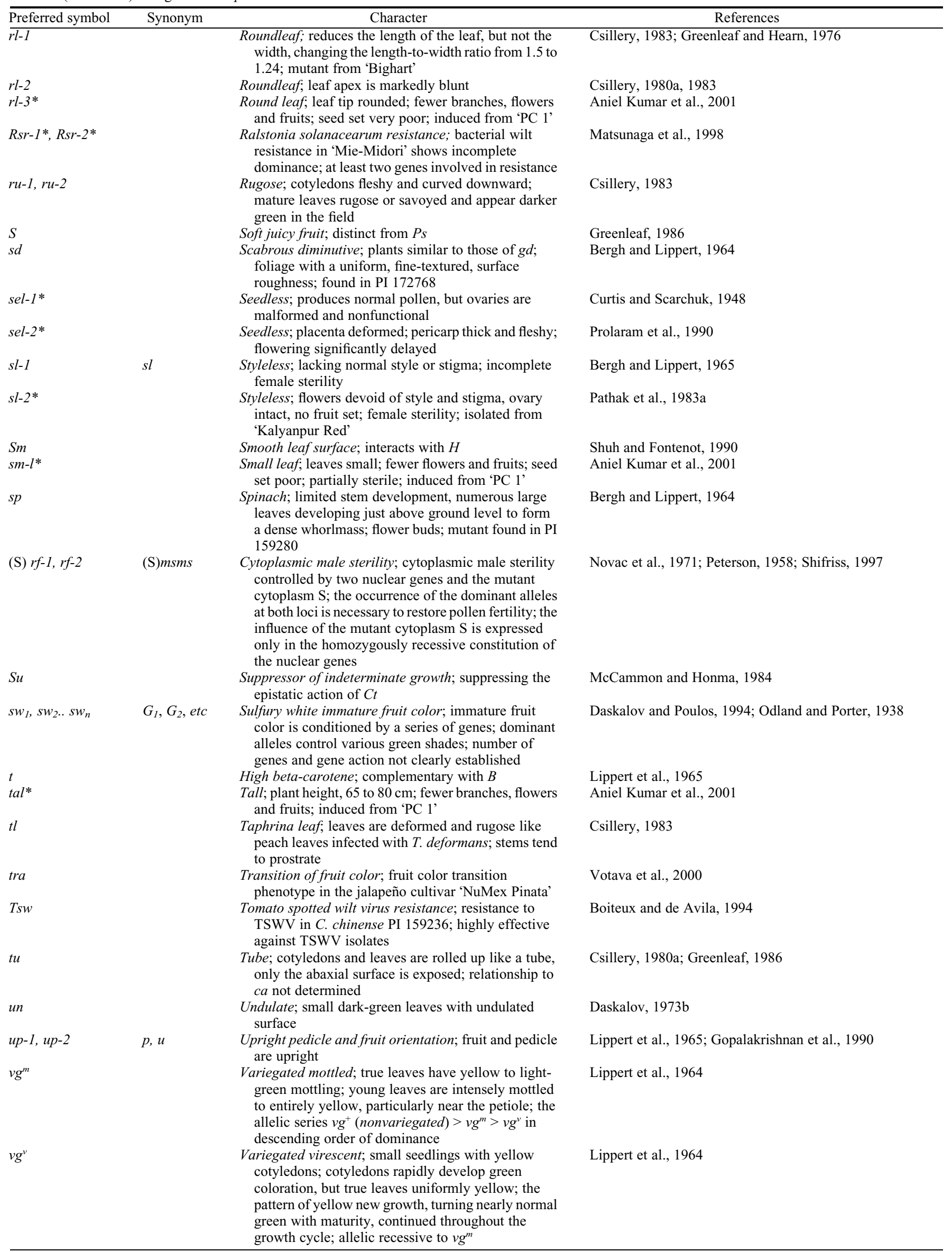


Table 1. (Continued) The genes of Capsicum.

\begin{tabular}{|c|c|c|c|}
\hline Preferred symbol & Synonym & Character & References \\
\hline$\overline{v i r-1}$ & vir & $\begin{array}{l}\text { Viridis; normal green cotyledons, true leaves yellowish } \\
\text { green }\end{array}$ & Daskalov and Poulos, 1994; Lippert et al., 1965 \\
\hline vir-2 & vir-a & $\begin{array}{l}\text { Viridis; young leaves are yellowish, but later change to } \\
\text { normal green; the mutant depends on 12-h day }\end{array}$ & Daskalov, 1973a; Daskalov and Poulos, 1994 \\
\hline$w l-1$ & $w l$ & $\begin{array}{l}\text { Willow leaf; leaves are slim and narrow; practically } \\
\text { female sterility }\end{array}$ & Bergh and Lippert, 1964 \\
\hline$w l-2$ & $w l-1$ & $\begin{array}{l}\text { Willow leaf; cotyledons nearly normal; leaves narrow } \\
\text { (8-12 mm in width); petals fused; corolla narrow } \\
\text { and crimped }\end{array}$ & Csillery, 1980a \\
\hline$x a-1$ to $x a-10$ & & $\begin{array}{l}\text { Xantha; seedlings white to yellow; cotyledons expand, } \\
\text { but plant dies in } 10 \text { to } 15 \mathrm{~d} \text {; } x a-1 \text { to } x a-8 \text { found in } C \text {. } \\
\text { annuum, xa- } 9 \text { in } C \text {. baccaturn, } x a-10 \text { in } C \text {. } \\
\text { pubescens; relation among } x a-1 \text { to } x a-10 \text { unknown }\end{array}$ & Csillery, 1980a, 1983; Lippert et al., 1965 \\
\hline$x a 2 a, x a 2 b$ & & $\begin{array}{l}\text { Xantha; similar to } x a-1 \text {, but dominated by two } \\
\text { complementary genes; relation to } x a-1 \text { to } x a-10 \\
\text { unknown }\end{array}$ & Lippert et al., 1965 \\
\hline$y$ & $r$ & Yellow mature fruit color; fruit color lemon yellow & $\begin{array}{l}\text { Hurtado-Hernandes and Smith, 1985; Lippert et al., } \\
\text { 1965; Smith, } 1950\end{array}$ \\
\hline$y a$ & & $\begin{array}{l}\text { Yellow anther; yellow anthers, but with purple spots on } \\
\text { the stem and fruits; found in 'Zlaten Medal' }\end{array}$ & Daskalov, 1974 \\
\hline$y c$ & & $\begin{array}{l}\text { Yellow cotyledon; yellow-white cotyledons, yellow- } \\
\text { green leaves, yellow ovary; golden yellow immature } \\
\text { fruits, light-red mature fruits }\end{array}$ & Daskalov and Poulos, 1994 \\
\hline$Y_{S}$ & & $\begin{array}{l}\text { Yellow corolla spot; found in C. baccatum var. } \\
\text { pendulum; acts as a dominant gene in crosses with } \\
\text { other species }\end{array}$ & Lippert et al., 1965 \\
\hline$y t-1, y t-2, y t-3$ & & $\begin{array}{l}\text { Yellow top; only the young, expanding leaves are } \\
\text { yellow, turn green gradually; } y t-3 \text { found in tetraploid } \\
\text { of C. annuum; relation to vir- } 2 \text { unknown }\end{array}$ & Csillery, 1980a, 1983 \\
\hline
\end{tabular}

*Proposed new gene symbols.

**Modified gene symbols that were previously published.

PED, peduncle; PVY, potato virus Y.

recessive, all letters of the gene symbol are in small letters. A gene symbol cannot be assigned to a character until supported by statistically valid segregating data (i.e., $F_{2}$ and $\mathrm{BC}$ populations). After validation by allelic tests, multiple alleles have the same symbol followed by a Roman letter or Arabic number superscript, and mimics may either have distinctive names and symbols, or the same gene symbol followed by a hyphen and a unique Arabic numeral or Roman letter. A modifying gene may have either a symbol for an appropriate name, such as intensifier, followed by a hyphen and the symbol of the allele affected, or a distinctive name. New gene symbols should not be assigned to preassigned symbols, nor should the same trait be described by more than one symbol. Priority in publication should be the primary criterion for establishing the preferred symbol when the same symbol has been inadvertently assigned to different genes or more than one symbol has been designated for the same gene or genes.

\section{Genes Determining Morphological Traits}

\section{Plant height}

Nine genes have been identified that affect plant height. Daskalov (1974) found two dwarf mutants, $d w-1$ and $d w-2$, in 'Zlaten Medal'. Csillery (1980b, 1983) reported two dwarf mutants from interspecific hybridizations - one from the interspecific hybridization between $C$. baccatum $\mathrm{L}$. and $C$. annuum $\mathrm{L}$., and the other between $C$. frutescens $\mathrm{L}$. and C. annuum - and found that they were con- ferred by $d w-3$ and $d w-4$, respectively. Restaino (1991) identified a new dwarf mutant from the local Italian variety, 'Friariello', that was controlled by $d w-5$, and was suitable for protected cultivation with high plant density. Yazawa and coworkers (1991) in Japan observed that some cultivars of $C$. annuum showed dwarfness in their interspecific hybrids with $C$. chinense no. 3341. This dwarfness was incited by an interaction between nuclear genes $d w-6$ and $d w-7$ from $C$. annuum and the cytoplasm of $C$. chinense. The gene was linked $6 \mathrm{cM}$ to the 610 -bp RAPD marker amplified with SSU-2F (Inai et al., 1993; Yazawa et al., 1991). Aniel Kumar and colleagues (2001) found a recessive gene, $d w-8$, conferring the dwarf phenotype, and a recessive gene, tal, that was responsible for a tall mutant induced from $C$. annuum cv. PC 1 .

The genetic conclusions of the plant height mutants were reached by using the mutants and the normal varieties from which these mutants were obtained. Interestingly, Todorov (1992) found that with the Romanian dwarf $C$. annuum variety Buketon, and the indeterminate, tall Bulgarian variety Gorogled 6, that plant height was controlled by two to three genes, with the environment having a stronger influence than genetic factors, suggesting additional genes may be involved in the genetic control of plant height.

\section{Flaccid phenotypes}

Four kinds of flaccid phenotypes have been described in Capsicum: diminished morphology ( $d m$ ) (Csillery, 1983), scabrous diminutive $(s d)$ (Bergh and Lippert, 1964), spinach ( $s p$ ) (Bergh and Lippert, 1964), and flaccidity $(f l c)$ (Bosland, 2002).

\section{Branching habits}

The $b l$ gene responsible for branchless plants of PI 169113 was identified by Bergh and Lippert (1964). The "umbrella" branching in MSU 79-221 (C. annuum) was controlled by three major recessive genes- $c t$, $d t$, and $f a-$ and modifiers (McCammon and Honma, 1984). Both $d t$ and ct control plant habit; $d t$ conditions determinate growth, whereas $c t$ determines the number of axillary shoots. The dominant alleles, $\mathrm{D} t$ and $\mathrm{C} t$, control indeterminate growth and are epistatic to one another. The $f a$ gene conditions the fasciculate or clustered fruit-bearing habit. The dominant suppressor gene, Su, suppresses the epistatic action of $C t$.

\section{Fasciculation}

Fasciculation in pepper is expressed as a shortening of internodes, resulting in compact, bushy plants, and expressed as flowers and fruits borne on bunched, compounded nodes conferred by the recessive $f a$ gene (Lippert et al., 1965). Van der Beek and Ltifi (1990) observed the variation in fasciculation, inferring that minor genes could be involved in the expression of fasciculation, operating in the presence of the $f a$ gene. The $f a$ gene showed tight linkage with a distance of $3.5 \mathrm{cM}$ to the $d t$ gene (Yang and Park, 1999).

\section{Leaf Shape}

Leaves with an undulate surface were conferred by the recessive gene un (Daskalov, 
1973b). Zubrzycki and Pahlen (1974) identified recessive anv and $b r l$ genes responsible for two leaf mutants (cited by Daskalov and Poulos, 1994). Later, Csillery (1980b, 1983) reported morphological mutants of cotyledons and leaves [i.e., filiform $(f i)$, willow leaf $(w l)$, canoe $(c a)$, tube $(t u)$, fan vein $(f v)$, round leaf $(r l-1, r l-2)$, rugose $(r u-1, r u-2)$, datura leaf $(d t r)$, small leaf $(s l-1)$, callus (call), frilly $(f r)$, procumbent hypocotyl $(p h)$ and polycotyledon $(p c-1, p c-2, p c-3)$, and $T l$ responsible for the taphrina leaf mutant. Aniel Kumar and colleagues (2001) described eight kinds of leaf mutants [i.e., narrow leaf $(n l)$, broad leaf $(b l)$, small leaf $(s l 2)$, curved leaf $(c l)$, folded leaf $(f l)$, round leaf tip $(r l-3)$, leaf dimorphism $(l d)$, and elongated petiole $(e p)]$ and determined that the mutant characters were controlled by single recessive genes. The allelism between $r l-1, r l-2$, and $r l-3$ was not determined. The allelism between $s l-1$ and $s l-2$ was also not identified. Leaf pubescence (HHSmSm) was dominant over glabrous leaf ( $h$ hsmsm), and was controlled by two dominant genes: $H$ and $S m$ (Shuh and Fontenot, 1990).

\section{Color of plant parts}

So far, color mutants of cotyledons, leaves, and stems have been described by Kormos and Kormos (1955) and Pahlen (1966) (cited by Daskalov and Poulos, 1994). Zubrzycki and Pahlen (1974) reported a mutant, aur, with golden cotyledons and leaves (cited by Daskalov and Poulos, 1994). Daskalov (1974) described a mutant, ya, with yellow anthers, but with purple spots on the stem and fruits. Later, Csillery (1980b, 1983) described color mutants of cotyledons, leaves, and stems, and showed that nine recessive genes $(x a-2$ to $x a-10)$ controlled the xantha mutants; 18 genes (lut-1 to lut-18) conferred the lutescens (yellow-green) mutants; three genes $(y t-1, y t-2$, and $y t-3)$ determined yellow top mutants; 52 genes (mos-1 to mos-52) were responsible for the mosaic mutants; one gene $(l \mathrm{sm})$, a lightsensitive mosaic mutant; and eight recessive genes (al-1 to al-8), the anthocyaninless mutants. The lut genes are not allelic to each other, nor are the mosaic genes allelic among mos-1 to mos-9. Recently, Ma coworkers (2001) in China reported a lutescens mutant conferred by gene lut-19. The allelism between lut-19 and lut-1 to lut-18 was not investigated. Daskalov (1987) identified one Flv gene determining yellow-green leaves (cited by Daskalov and Poulos, 1994). The relationship between $l u t$ and $F l v$ remains unknown.

An incompletely dominant gene, $A$, controls the anthocyanin color of stem, foliage, flowers, and immature fruits. The $A$ gene is effective only in the presence of $a l^{+}$. In $A A$ genotypes, the action of the $A$ gene is intensified by a gene modifier, MoA (being ineffective alone). Additional genes for differential anthocyanin accumulation in flower $(R-1$ and $R-2)$, style $(A s)$, style and filament $(A s f)$, and immature fruits $(F)$ have been also reported. Odland (1960) found that the flower colors were conditioned by three genes ( $S, W$, and $A$ ). The $M o A$ locus was localized to chromosome 11 by sharing a linkage with $L$ that confers resistance to tobacco mosaic virus (TMV) (Ben Chaim et al., 2003). The $A$ gene was assigned to chromosome 10 (Ben Chaim et al., 2003) and the gene $F c$ controlling the purple anther-filament color was assigned to chromosome 10 (Prince et al., 1993). The map position of $A$ was identical to $F c$, indicating that the two loci are allelic (Ben Chaim et al., 2003). A linkage of $6.5 \mathrm{cM}$ between $A$ and $O$, the gene that controls round fruit shape in $C$. annuum, was reported (Peterson, 1959) and recently verified (Ben Chaim et al., 2003). Ben Chaim and colleagues (2003) also reported that the $F c$ locus was linked to a major quantitative trait locus, $f s 10.1$, for fruit shape index (ratio of fruit length to fruit width).

\section{Variegated seedlings}

Six types of variegated seedlings have been reported. Hagiwara and Oomura (1947) reported the pi gene was responsible for green and white leaf variegation (cited by Lippert et al., 1965). Cook (1962) showed that the $b v$ gene was responsible for the bushy variegated mutant. Lippert and colleauges (1964) and Daskalov $(1974,1977)$ found four mutants with marbled leaves that were controlled by four genes: $m-1, m-2, m-3$, and $m-4$ (cited by Daskalov and Poulos, 1994). The variegated mottled mutant and variegated virescent mutant were controlled by the $v g^{m}$ and $v g^{v}$ genes respectively (Lippert et al., 1964). The greenish yellow variegation mutant was conditioned by the $\mathrm{chl}$ gene (cited by Lippert et al., 1965), and Zubrzycki and Pahlen (1974) determined that the deformed and undulated green virescent variegated leaves were conferred by the gene $d v g$ (cited by Daskalov and Poulos, 1994).

\section{Flowers}

Multiple flowers are controlled by three major dominant genes: $M f-1, M f-2$, and $M f-3$ (Shuh and Fontenot, 1990). The expression of multiple flowers occurs when $M f-1$ _ is present and either $M f-2$ or $M f-3$ is present. Recessive homozygosity at the $M f-1$ locus reduces the multiple-flower nodes despite dominant genes present at both $M f-2$ and $M f-3$. Two genes affecting the time of flowering have been identified (Aniel Kumar et al., 2001): the gene ef for early flowering and the gene $l f$ for late flowering. Pathak and associates (1985) found a nonflowering mutant that was controlled by a monogenic recessive gene $n f$. Two closedflower mutants are conditioned by the $c f-1$ and $c f-2$ genes (Pathak et al., 1983; Subramanya and Ozaki, 1984).

\section{Fruit shapes}

Six genes have been identified to affect the characteristics of fruit shape. Deshpande (1933) described the dominant gene $P$ for pointed fruit apex, the recessive gene $f b$ for fruit base nonbulging, and the gene $c e$ for calyx enclosed around fruit base (Daskalov and Poulos, 1994). The round fruit shape is controlled by the major dominant gene $O$ and other modifiers (Peterson, 1959), and recent molecular mapping studies confirm the existence of the major genes that control this trait (Ben Chaim et al., 2001, 2003; Rao and Paran, 2003). Upright fruit orientation is controlled by two recessive genes-up-1 and $u p-2$ - that show specific dominant and recessive epistasis respectively (Gopalakrishnan et al., 1990; Lippert et al., 1965). Csillery (1983) identified the recessive gene, $c y$, responsible for the exocarp covered with transversally oriented, small suberized cracks at full fruit maturity. Ishikawa and coworkers (1998) reported the dominant $A p$ and Ped genes to condition the pointed shape of the fruit apex, and the acute shape of the fruit pedicle attachment respectively. The allelism between $A p$ and $P$ is unknown. Parthenocarpy is conferred by the $p f$ gene from the variety 'Kalyanpur Chaman' (Pathak et al., 1983b).

\section{Immature fruit color}

Immature fruit color is conditioned by a series of alleles (Odland and Porter, 1938). The sulfur white, $s w_{1}$, locus controls the various white and green shades of the fruit. The lettuce or yellowish green color, $s w_{2}$, is dominant to the sulfury white, $s w_{1}$, and recessive to the cedar green, $s w_{3}$, whereas cedar green, $s w_{3}$, is dominant to sulfury white.

\section{Mature fruit color}

Early studies found that the mature yellow color of Capsicum fruits is recessive to red and controlled by a single gene $y$ (yellow) (Boswell, 1937). Smith (1950) found that the brown color of ripe pepper fruit was the result of the combination of the normal red pigment and the retention of chlorophyll. The brown color is governed by two genes: $\mathrm{cl}$ for retention of chlorophyll and $y^{+}$for red color. Hybridizations between red and white fruit varieties have shown that the mature fruit color is controlled by three genes: $c-1, c-2$ and $y$ (Hurtado-Hernandez and Smith, 1985). The $c-1$ gene affects the amount, rather than the type, of carotenoids present, and the gene $c$-2 has a significant effect on the total level of carotenoid accumulation in fruit. The $c-1$ and $c-2$ genes reduced the pigmentation of $y$ and $y^{+}$by the inhibition of beta-carotene. Popovsky and Paran (2000) demonstrate the effect of the genetic background on fruit color segregation and provide additional evidence for two possible genotypes of the orange fruit color. In addition, the $i m$ gene was found to condition purple color at intermediate maturity in originally nonpurple immature fruit (Lippert et al., 1965).

The gene Ccs, coding for capsanthincapsorubin synthase that synthesizes the red carotenoid pigments, corresponds to the morphological locus $y$ (Lefebvre et al., 1998; Popovsky and Paran, 2000). Ccs, a singlecopy gene in pepper, was assigned to pepper chromosome 6, $1 \mathrm{cM}$ away from CT109. A QTL affecting the intensity of mature red color was also detected in this region (Thorup 
et al., 2000). A 500-bp fragment amplified by primer OPN-7 is linked with $C c s / Y$ at a distance of $7 \mathrm{cM}$ (Thorup et al., 2000). In addition, one QTL affecting red chroma and another affecting red lightness were identified on chromosome 3 in an intraspecific $C$. annuum population (Thorup et al., 2000).

The locus $C 2$ cosegregated with phytoene synthase, Psy (Thorup et al., 2000), which is the locus responsible for the development of fruit color. $P s y / C 2$ may be a major gene acting as a rate-limiting factor in carotenoid production. Psy is the candidate for $C 2$ (Huh et al., 2001). A 700-bp fragment amplified by the primer OPO-12 and a 900-bp fragment amplified by the primer UBC-183 were mapped to chromosome 4 , and were found to be $1 \mathrm{cM}$ apart from each other and $36 \mathrm{cM}$ away from $P s y / C 2$ (Thorup et al., 2000). A QTL affecting the red hue of fruit was also mapped to this region (Ben Chaim et al., 2001), implicating Psy as a source of both qualitative and quantitative variability in carotenoid biosynthesis.

\section{Transition of fruit colors}

Votava and associates (2000) noticed that the jalapeño cultivar, NuMex Piñata, had a unique transition of colors as the fruit matures, from light green in immature fruits, maturing to yellow, then orange, and finally to red. It was determined that the inheritance of luteous foliage color and fruit color transition phenotype of 'NuMex Piñata' is the result of a single homozygous recessive gene: tra (transition).

\section{Genes Determining Physiological Traits}

\section{Pungency}

Pungency, or the sensation of heat when eating pepper fruit, comes from the presence of the capsaicinoid alkaloids in the fruit. Early genetic studies reported that a single dominant gene $C$ controlled the expression of heat (Deshpande 1935, Greenleaf, 1952), which can be modified by other genetic and environmental factors. This gene was later redesignated Pun (Daskalov and Poulos, 1994), and probably functions as an acyltransferase to complete the capsaicinoid synthesis (Stewart et al., 2005). Loaiza-Figueroa and Tanksley (1988) reported a second nonpungency locus, pun2, in a wild, nonpungent pepper accession BG 3547; however, further studies cannot support the existence of this locus - most likely the nonpungent accession was expressing the lov gene (Votava and Bosland, 2002). Votava and Bosland (2002) described two novel nonpungent $C$. chinense accessions 'NMCA 30036' and 'PI 543190', in which loss of the vesicles (lov) on the placental walls is responsible for nonpungency. The lov gene is epistatic to punl and results in pungent progenies. Blum and associates (2002) mapped the Pun locus to chromosome 2 in a hybridization between a pungent $C$. frutescens accession and a noheat $C$. annuum bell pepper, and developed a polymerase chain reaction-based cleaved amplified polymorphic sequence (CAPS) marker linked to Pun using the sequence of the Capsicum fibrillin gene located $0.4 \mathrm{cM}$ from Pun. Recently, the Pun-1 gene was cloned and characterized based on the candidate gene approach (Stewart et al., 2005). The full-length genomic sequence of Pun-1 is $1897 \mathrm{bp}$, containing two exons of $738 \mathrm{bp}$ and $585 \mathrm{bp}$ respectively, and one intron of $348 \mathrm{bp}$. The pun- 1 allele results from a large deletion at this locus.

\section{Beta-carotene contents}

Three genes- $B, t$, and $b c$-have been identified that confer high beta-carotene contents of ripe fruits. Chalukova and colleauges (1993) and Daskalov and coworkers (1995) described the mutant variety Orangeva Kapia obtained from 'Pasardzhishka Kapia'. This mutant variety produces immature green fruits and mature orange fruits containing 2 to 2.5 -fold higher contents of beta-carotene than their red counterparts. High betacarotene content in this mutant variety is conferred by a recessive gene, $b c$, which prevents hydroxylation of beta-carotene to beta-cryptoxanthin.

\section{Soft flesh and deciduous fruits}

Smith (1951) found the deciduous ripe fruit character to be controlled by a single dominant gene, $S$. Later, Jeswani and associates (1956) obtained similar findings for this trait (cited by Greenleaf, 1986). Kormos and Kormos (1957) reported that the softfruited trait was controlled by the dominant gene Ps (cited by Greenleaf, 1986). The genetic reports of these two traits were independent, so the two traits were considered as distinct from each other (Daskalov and Poulos, 1994; Greenleaf, 1986). In the gene lists of Daskalov and Poulos (1994), and Greenleaf (1986), the gene symbol $S$ given by Smith (1951) to the deciduous fruit trait was assigned to the soft flesh trait, and the gene symbol $P s$ was reassigned to the pod separation trait and is considered distinct from $S$. However, the fruits of the wild $C$. frutescens accession BG2816 were both deciduous and had soft flesh, and these two traits cosegregated in the $F_{2}$ progenies of 'BG2816' and the cultivar Maor (C. annuum). Therefore, it is likely that both characteristics in $C$. frutescens BG2816 are controlled by the same gene with pleiotropic effects (Rao and Paran, 2003). $S$ is mapped to chromosome 10 , and the polygalacturonase (PG) gene $P G$ is a candidate gene for $S$ (Rao and Paran, 2003).

\section{Genes Determining Sterility Traits}

\section{Genic male sterility}

Nearly 20 genes for genic male sterility have been reported. Shifriss and Frankel (1969) named the first male sterile gene $m s-1$ in a spontaneous stable male sterile mutant from the C. annuum cv. All Big. A second male sterile gene, $m s-2$, was identified in a spontaneous stable male sterile mutant from 'California Wonder' (Shifriss and Rylski, 1972). Daskalov (1973b) identified five genes $(m s-3, m s-4, m s-6, m s-7$, and $m s-8)$ conferring male sterility in the irradiationinduced mutants. These seven nonallelic genes are mainly expressed as pollen sterility. Pochard found three genes $(m s-9, m s-10$, and $m s-11$ ) in three male sterile mutants obtained after treatment of monoploid materials with ethyl methansulphonate (EMS) (cited in Daskalov and Poulos, 1994). Shifriss (1973) reported a recessive gene, $m s-12$, governing the male sterility in a spontaneous mutant from C. annuum cv. Gambo. Meshram and Narkhede (1982) identified the $m s-13$ gene that conditions male sterility in a mutant from C. annuum cv. Ca452-1. Pathak et al., (1983) isolated a male sterile mutant from cv. 'Kalyanpur Selection', and proved that male sterility was governed by the single recessive gene $m s-14$. In India, Deshpande and coworkers (1983) presented more than 20 male sterile mutants in India, whereas in China two genic male sterile genes ( $m s c-1$ and $m s c$-2) have been used to produce $\mathrm{F}_{1}$ sweet pepper hybrids (Yang, 1981; Yang et al., 1994). Daskalov (1987) also reported a dominant genetic male sterility gene: Dms (cited in Daskalov and Poulos, 1994).

According to morphological changes exhibited in androecium, the male sterile mutants can be grouped into six categories (Deshpande et al., 1983): 1) androecium transformed into petaloid structure $(m s-13)$; 2 ) shriveled anthers devoid of pollen grains, including $m s-1, m s-3, m s-6$, and $m s-8$ (Daskalov, 1974); 3) anthers that are not reduced severely and contain a small amount of fertile and sterile pollen grains in some flowers ( $m s-4$ and $m s-7$ ) (Daskalov, 1974); 4) shrunken anthers that release numerous aborted pollen grains $(m s-2)$ (Shifriss and Rylski, 1972); 5) anthers that appear to be normal, but pollen grains are sterile; and 6) yellow anther lobes that are flattened laterally to give an appearance of a fan blade and are devoid of pollen grains (Deshpande et al., 1983).

\section{Cytoplasmic male sterility (CMS)}

The inheritance of CMS in C. annuum was first studied by Peterson (1958), who showed that sterility was controlled by a major gene, $m s$, interacting with a specific $S$ plasma type to generate (S) msms CMS plants. He also suggested that the second allelic pair was probably in another linkage group. Novac and colleagues (1971) worked with Peterson's male sterile material and found that the male sterility was conditioned on two pairs of nonallelic nuclear genes. Both the nuclear genes $m s-1$ and $m s-2$ have complementary genic interaction. The presence of at least one dominant allele at both loci is necessary to restore the pollen fertility in the plants with the S cytoplasm. Daskalov (1974) identified a CMS mutant from the variety 'Kalinkov 800/7' that is not identical with Peterson's (1958) CMS line, and found that this male sterility was probably conferred by more nuclear genes, including the gene originally designated $m s-5$, and the $\mathrm{S}$ factor in the cytoplasm. In China and Korea, some CMS lines have been used to produce commercial $F_{1}$ hybrids (Wang et al., 2003), but the 
relationship between these CMS lines and Peterson's (1958) CMS line has not been evaluated.

Shifriss (1997) suggested the nuclear gene conferring CMS be redesignated $r f$ and the restorer of fertility allele as $R f$ to differentiate between the $m s$ genes in genic male sterility lines and the male sterility genes interacting with $\mathrm{N}$ and $\mathrm{S}$ cytoplasm that were originally designated as $m s$ genes (Daskalov, 1974; Peterson, 1958). The $m s$ genes are nonallelic to the $r f$ ones. Two RAPD markers tightly linked to a major fertility restorer gene were detected (Zhang et al., 2000): OP13 1400 with a genetic distance of $0.37 \mathrm{cM}$, and OW19 ${ }_{800}$ on the opposite side with a distance of $8.12 \mathrm{cM}$. Recently, Kim and Kim (2005) developed two CMS-specific sequence-characterized amplified region (SCAR) markers for early identification of CMS genotype based on the restriction-length polymorphisms between male fertile and CMS cytoplasms at the coxII and atp6 loci of the mitochondrial DNA of $C$. annuum.

\section{Functional male sterility}

Yuan and Li (2000) reported a spontaneous stable functional male sterile mutant from the cultivar Fudijian (C. annuum) and determined that this functional male sterility was controlled by a recessive gene: fms.

\section{Female sterility}

Six types of female sterile mutants have been reported: 1) the female sterility mutant conferred by the recessive $f s$ gene (Bergh and Lippert, 1964); 2) two female and male sterility mutants conferred by recessive fems and $f l$ genes respectively (Aniel Kumar et al., 2001; Martin and Crawford, 1951); 3) a female sterile mutant with $27 \%$ to $55 \%$ pollen fertility conditioned by the recessive $f c f$ gene (Pahlen, 1967; cited by Daskalov and Poulos, 1994); 4) two styleless mutants controlled by recessive genes $s l-1$ and $s l-2$ (Bergh and Lippert, 1965; Pathak et al., 1983b); 5) two seedless mutants conditioned by recessive genes sel-1 and sel-2 (Prolaram et al., 1990); and 6) 'complex' mutants. The genes $s p, b l, f i-1, p r p$, and pec have marked effects on both vegetative organs and female fertility (Bergh and Lippert, 1964; Csillery, 1983). Allelisms between $s l-1$ and $s l-2$ are unknown. A conditional female sterility gene, $c f s$, was identified by Daskalov and Mihailov (1988).

\section{Genes Determining Resistance to Diseases, Nematodes, and Herbicides}

\section{Resistance to tobacco mosaic virus (TMV)}

Holmes (1937) found that resistance to TMV was controlled by a series of multiple alleles: $L$ (localization of TMV), $L^{i}$ (imperfect localization of TMV), and $L^{+}$(mottling), with $L>L^{i}>L^{+}$. Boukema et al. (1980a) determined that the resistance of $10 C$. chinense accessions (PI 152225, PI 159236, PI 315008, PI 315023, PI 315024, PI 159223, PI 213917, PI 257117, PI 257284, and PI 224424) was inherited monogenically and was partially dominant, and that the resistant genes in these accessions appeared to be allelic and were allelic with the alleles $L^{i}$ and $L$. She designated the symbol $L^{3}$ for the new allele, and redesignated Holmes's allelic series $L>L^{i}>L^{+}$as $L^{3}>L^{2}>L^{1}>L^{+}$. Later, Boukema (1984) reported that the $L^{4}$ allele originated from C. chacoense PI 260429 and SA185. Recently, Salamon and associates (2001) revealed the resistant allele $L^{2 g}$ in 'Greygo', which behaved like the allele $L^{2}$ with characteristics of $C$. frutescens cv. Tabasco. The identity of the allele $L^{2 g}$ relative to $L^{2}$ is not known.

However, the conferred resistance of $L$ locus lessens when the air temperature surpasses $30{ }^{\circ} \mathrm{C}$ (Palloix, 1992). Daubeze and colleagues (1990) revealed the presence of secondary genes that stabilize the expression of $L^{l}$ under high temperature $\left(32^{\circ} \mathrm{C}\right)$. Such modifier genes were found in Chinese accessions ('Zao Feng' and 'Ben Xi') with $L^{l}$, but also in tropical varieties susceptible to TMV ('Perennial' and 'PI 322719'). The Mexican variety Criollo de Morelos 334 (CM 334) also bears a particular allele at the $L$ locus that confers resistance to TMV (0) at high temperatures, and secondary genes that control the rapid production of smaller local lesions in the inoculated organs (Palloix, 1992).

Zatyko and Moor (1998) confirmed a close linkage between the $a l$ and $L^{3}$ genes in the pepper line 'TL 791'. SCAR marker WA31$1500 \mathrm{~S}$ was linked to the $L^{4}$ gene within a distance of $1.5 \mathrm{cM}$ (Matsunaga et al., 2003).

\section{Resistance to cucumber mosaic virus (CMV)}

Resistance to CMV has showed the characteristics of genetic diversity (for a review see Wang et al., 1996). Some accessions have the recessive resistance gene (Cook, 1982; Herison et al., 2004; Singh and Thakur, 1977), some have oligogenes (Herison et al., 2004; Saito et al., 2004), and others carry polygenic resistance (Greenleaf, 1986; Pochard et al., 1983). Singh and Thakur (1977) confirmed a recessive gene with resistance to CMV in the line 'Perennial', and designated the gene symbol $\mathrm{cm}$. Resistance in 'Perennial' was under polygenic control (Gil-Ortega and Arteaga, 1988), and four QTLs were significantly associated with resistance to CMV in this line, among which the QTL-controlling percentage $(16 \%-33 \%)$ of the observed phenotypic variation was linked to the $L$ locus that confers resistance to TMV (Ben Chaim et al., 2001). Pochard (1982) designated three resistant components of partial resistance to $\mathrm{CMV}$, (i.e., tendency to escape infection, restriction of viral multiplication, and slowing of viral migration in the resistant reaction to $\mathrm{CMV}$ in different cultivars). Later, researchers added four more resistance components - namely, the ability to recover from systemic infection (Pochard and Daubeze, 1991), restriction of virus installation in host cells (Caranta et al., 1997b), restriction of virus multiplication in the whole plant (Nono-Wondim et al., 1993), and restriction of long-distance virus movement (Caranta et al., 2002). Three QTLs significantly affecting restriction of CMV installation in host cells were detected, and each QTL from 'Perennial' was associated with an increased resistance (Caranta et al., 1997a). Partial restriction of CMV long-distance movement in 'Vania' is inherited as a dominant trait, and seven QTLs, including one major-effect and several minor-effect QTLs, were associated with this resistance (Caranta et al., 2002). The genes for resistance to CMV are not linked with those genes conferring fruit weight and size (Shifriss and Cohen, 1987).

\section{Resistance to potyvirus}

Pepper may be infected by six major potyviruses: potato virus $\mathrm{Y}$ (PVY), tobacco etch virus (TEV), pepper mottle virus (Pep$\mathrm{MoV})$, pepper veinal mottle virus (PVMV), chile veinal mottle virus (CVMV), and potyvirus E (PVE) (Green and Kim, 1991). PVY isolates have been traditionally classified into three pathotypes (-0, -1, and -1.2) (Cook, 1963; Gebre Selassie et al., 1983). Recently, a new pathotype has been described and provisionally named as PVY-PRW (Luis Arteaga et al., 1997). The gene designations of resistance in Capsicum to three potyviruses (PVY, TEV, and PepMoV) have not followed regular convention, so confusion has occurred. Kyle and Palloix (1997) proposed a nomenclature that clarifies the genetic and biological relationships among potyvirus resistance genes in Capsicum. They proposed the symbol $p v r$ for the potyvirus resistance locus. Until now, eight major resistance genes ( $p v r$ genes) and several QTLs showing phenotypically distinct types of responses to potyvirus. The $p v r-1$ gene is the locus with alleles for recessive resistance to TEV and PepMoV in 'PI 152225' (Greenleaf, 1956) (originally $e t^{f}$ and $e t^{c}$ ) and 'PI 169236' (Greenleaf, 1986) (originally et $t^{c l}$ and $e t^{c^{2}}$ ). These PI accessions are allelic for PepMoV resistance and for TEV resistance (Murphy et al., 1998). An allelic series at the pvr-2 locus controls the recessive resistance to PVY (Kyle and Palloix, 1997). For resistance to PVY (0), the resistance allele $p v r$ $2^{l}$ replaces $y^{a}$ and $v y^{l}$ from 'Yolo RP10' and 'Yolo Y' respectively, (Cook, 1960, 1961a; Gebre Selassie et al., 1983). For resistance to PVY (1) and TEV derived from 'SC46252' and introduced to 'Florida VR2', $p v r-2^{2}$ replaces $e t^{a}, e y^{a}$, and $v y^{2}$ (Cook and Anderson, 1959; Gebre Selassie et al., 1983).

In addition, a polygenic resistance to PVY from 'Perennial' was dissected into a combination of QTLs, including a major-effect gene that was mapped to the pvr-2 locus (Caranta et al., 1997a). Ayme and colleagues (2004) proposed the name $p v r-2^{3}$ for this major-effect gene at the pvr-2 locus. Both $p v r-2^{1}$ and $p v r-2^{2}$ alleles are shown to correspond to the eukaryotic translation initiation factor 4E (eIF4E) (Ruffel et al., 2002). Recently, genetic complementation analysis demonstrated allelism of $p v r-1, p v r-2^{1}, p v r-$ $2^{2}$, and $p v r-2^{3}$ (Kang et al., 2005; Ruffel et al., 2004). Hence, $p v r-2^{1}$ and $p v r-2^{2}$ have been redesigned $p v r-1^{1}$ and $p v r-1^{2}$ respectively 
(Kang et al., 2005). The third locus, pvr-3, was proposed for an allele for monogenic recessive potyvirus resistance to $\mathrm{PepMoV}$ in C. annuum 'Avelar' (Zitter and Cook, 1973).

Several resistance genes against potyviruses have been described in CM 334; the $P v r-4$ locus was named for a gene that gives resistance to all known pathotypes of PVY and to PeMV in C. annuum CM 334 (Boiteux et al., 1996; Dogimont et al., 1996; Palloix, 1992; Pasko et al., 1992). Pasko and coworkers (1992) described several levels of resistance in CM 334 against different PVY pathotypes. CM 334-derived materials show different responses, indicating that, besides the $P v r-4$ allele, other genes conferring resistance at different levels are also present (Arnedo-Andres et al., 1998). The gene conferring only the resistance to PVY (0) in CM 334 was designated pvr-5 (Dogimont et al., 1996).

The gene $P n-1$ confers the necrotic response to PVY $(0,1,2)$ isolates in 'Vat'. The genetic control for the appearance of systemic necrotic symptoms in 'CM 334(11)' after inoculation of PVY (1-2) isolate P-2288 is the result of a codominant gene expressed only when $P v r-4$ is not present and with a maximum expression that is observed in the homozygous condition (ArnedoAndres et al., 2004).

A recessive gene for resistance to PVMV from 'Perennial' is designated $p v r-6$ (Caranta et al., 1996). The gene $p v r-6$ is complementary to the $p v r-1$ locus for resistance to PVMV. The dominant gene, $P v r-7$, from $C$. chinense Jacq. 'PI 159236', confers resistance to PepMoV Florida (V1182) strain (Grube et al., 2000). This gene is tightly linked to the dominant potyvirus resistance gene, $P v r-4$, with observed recombination frequencies of 0.012 to 0.016 . Resistance to PVY in the A97011 line, derived by intraselection from CM 334, is controlled by a recessive and independent gene: $p v r$ - 8 (Arnedo-Andres et al., 2004).

Caranta and Palloix (1996) found the polygenic resistance of 'Perennial' (C. annuum) to PVY (0), PVE, and CVMV, and a partial resistance to PVY $(1,2)$ was due both to genetic factors that apparently interact with several viruses, and strain-specific genetic factors. Later Caranta and colleagues (1997a) proved that the polygenic resistance in 'Perennial' to PVY and PVE consists of a combination of isolate-specific and broadspectrum QTLs. In their studies, 11 chromosomal regions were determined to be associated with quantitative resistance in 'Perennial' to PVY and PVE. QTLs for potyvirus resistance, in some cases, coincide with positions for $p v r$ loci. QTLs for PVY and PVE resistance are detected in the vicinity of the $p v r-2$ and $p v r-6$ loci. These results suggest a possible allelism between major genes and QTLs.

The modes of action of these major resistant genes have been determined. $p v r-1$ and $p v r-2^{2}$ both control a complete inhibition of virus accumulation in infected cells (Deom et al., 1997); $p v r-2^{l}$ impairs cell-to-cell movement (Ponz et al., 1994; Arroyo et al., 1996) whereas $p v r$-3 slows long-distance movement (Murphy and Kyle, 1995). Interaction between the potyvirus genome-linked protein $(\mathrm{VPg})$ and eIF4E are important for PVY virus infectivity, suggesting that the $p v r-2$ recessive resistance could be the result of incompatibility between the VPg and eIF4E in the resistant genotype (Ruffel et al., 2002). Moury and associates (2004) pointed out that 15 nucleotide changes corresponding to five putative amino acid differences in the same region of the VPg of PVY affected virulence toward the $p v r-2^{I}$ and $p v r$ $2^{2}$ resistances. Both the Pvr-4 and pvr-5 control a complete inhibition of potyvirus replication or accumulation. This mechanism is pathotype specific when controlled by $p v r$ 5 , whereas it is effective against three different pathotypes and against PepMoV as well when controlled by Pvr4 (Caranta et al., 1998).

The pvr-1 locus, linked with tomato marker TG56, has been genetically mapped to a small linkage group with synteny to the short arm of tomato chromosome 3 (Murphy et al., 1998). Yeam and colleagues (2005) developed the allele-specific CAPS markers based on point mutations in resistance alleles at the pvr-1 locus encoding eIF4E in Capsicum. Arnedo-Andres and associates (2002) identified one RAPD marker (UBC19 1432) linked in repulsion phase to Pvr-4 and converted it into a dominant SCAR marker (SCUBC19 1423 ). Caranta and associates (1999) mapped eight amplified fragment length polymorphism (AFLP) markers in an interval from $2.1 \pm 0.8$ to $13.8 \pm 2.9 \mathrm{cM}$ around the Pvr-4 locus, and converted the closest codominant AFLP marker into a codominant CAPS marker.

\section{Resistance to tomato spotted wilt tospovirus (TSWV)}

The hypersensitive resistance to TSWV was determined by a single gene, $T s w$, in three $C$. chinense Jacq. accessions (PI 152225, PI 159236, and 7204). All three C. chinense lines have the same allele located at the Tsw locus (Moury et al., 1997), and showed the identical susceptibility response to tomato chlorotic spot virus and groundnut ringspot virus isolates after mechanical inoculation (Boiteux, 1995). The TSWV resistance controlled by the $T s w$ gene is completely stable at a lower temperature $\left(22{ }^{\circ} \mathrm{C}\right)$ and is less stable at $32^{\circ} \mathrm{C}$ continuous temperature (Moury et al., 1997). Luis Arteaga and Gil Ortega (1998) proved that the susceptibility of $C$. chinense could occur at low $\left(22.5^{\circ} \mathrm{C}\right)$ and high $\left(30^{\circ} \mathrm{C}\right)$ temperatures on both young and adult plants.

Genetic background was significantly less involved in the thermosensitivity of this resistant response. Heterozygosity at the $T s w$ locus enhanced the chance of inoculated seedlings to develop systemic necrotic symptoms (Moury et al., 1998). One codominant CAPS marker is tightly linked to $T s w$ $(0.9 \pm 0.6 \mathrm{cM})$ and is helpful for markerassisted selection in a wide range of genetic intercrosses (Moury et al., 2000). The Tsw gene is mapped to the distal portion of chromosome 10 (Jahn et al., 2000).

\section{Resistance to bacterial leaf spot}

Currently, nine pepper races (P0-P8) have been identified among Xanthomonas campestris pv. vesicatoria $(X c v)$ strains worldwide (Sahin and Miller, 1998). Four nonallelic dominant genes $(B s-1, B s-2, B s-3$, and $B s-4)$ were reported to control hypersensitive reaction to $X c v$ according to the genefor-gene hypothesis, and were found in PI 163192, PI 260435, PI 271322, and PI 235047 (Cook and Guevara, 1982, 1984; Cook and Stall, 1963; Hibberd et al., 1987; Kim and Hartmann, 1985; Sahin and Miller, 1997). The $B s-2$ gene from $C$. chacoense specifically recognizes and confers resistance to strains of $X c v$ that contain a virulence gene avrBs 2 (Minsavage et al., 1990). The Bs-2 gene is a member of the nucleotide binding site leucine-rich repeat class of plant disease resistance genes (Tai et al., 1999a), and is predicted to reside in the plant cytoplasm.

Recently Jones and colleagues (2002) found a nonhypersensitive resistance to race 6 in the pepper genotype ECW-12346 that was developed with bacterial spot resistance derived from 'Pep13', PI 271322, and ECW123 (Early CalWonder containing $B s-1, B s-2$, and $B s-3$ genes), and identified that two recessive genes- $b s-5$ and $b s-6$ derived from PI 271322 and 'Pep13' respectivelydetermined this resistance. ECW12346 inhibits the population buildup of this $\mathrm{XcV}$ strain without inducing the typical hypersensitive reaction. Hungarian scientists described another type of nonhypersensitive resistance against $X c v$ in $C$. annuum PI 163192, which used a general defense system of the host plant (Csillery et al., 2004; Szarka and Csillery, 1995). This resistance is regulated by a recessive gene: gds (general defense system). This gene localizes the pathogen with an entirely different strategy than the hypersensitive reaction. The resistance conditioned by $g d s$ promotes cell growth and cell wall thickening.

The instability of avirulence genes in $\mathrm{Xcv}$ has stimulated the interest for quantitative resistance. Accession CNPH703 was identified with a race nonspecific and nonhypersensitive resistance to $X c v$, and low narrow-sense heritability for three components of resistance: lesion number, lesion diameter, and total lesion area (Poulos et al., 1991). Poulos and colleauges (1992) determined that dominance, additive, and interacting gene effects of at least two genes were involved in the inheritance of quantitative resistance to $\mathrm{Xcv}$ in 'CNPH703'.

Tai and associates (1999b) identified one AFLP marker, A2, cosegregated with the $B s-2$ locus, and two other markers, F1 and B3, flanking the $B s-2$ locus and being within $0.6 \mathrm{cM}$. Also, two RAPD markers, OPD05 and OPF10, were identified to link with the $B s-2$ gene (Kim et al., 2001). OPD05 was located $5.3 \mathrm{cM}$ from $B s-2$ gene whereas OPF10 was located $4.9 \mathrm{cM}$ from the $B s-2$ on the opposite 
side to OPD05. SCAR marker SCF10, originating from marker OPF10, was successfully obtained. Based on the most tightly linked AFLP markers, a 2.1-cM genomic target interval encompassing the $B s-3$ locus was defined by Pierre and colleauges (2000). $B s-3$ is separated from the marker P23-70 and P22-3 by only $1 \mathrm{cM}$ and $1.1 \mathrm{cM}$ respectively.

\section{Resistance to phytophthora}

Phytophthora capsici Leon. causes several disease syndromes (i.e., phytophthora root rot, stem rot, foliar rot, and fruit rot) (Sy et al., 2005; Walker and Bosland, 1999). Resistance to Phytophthora root rot exhibited the characteristics of genetic diversity (for a review see Wang et al., 1995). A single dominance gene was present in some accessions (Choi et al., 1990; Kim and Hur, 1992), oligogenes in some accessions (Cristinzio et al., 1992; Gil Ortega et al., 1991, 1992; Reifschneider et al., 1992), and quantitative genes in others (Thabuis et al., 2003). One dominant gene was necessary for resistance in CM 334 when the susceptible parent was 'Early Jalapeno' (Sy et al., 2005; Walker and Bosland, 1999).

A single dominant gene, Psr, conferred stem resistance in 'Criollo de Morelos-334' when choosing 'Early Jalapeño' as a susceptible parent (Sy et al., 2005). A dominant gene, $P f o$, was required for foliar resistance in CM 334 when the susceptible parent was 'Early Jalapeño' (Sy et al., 2005; Walker and Bosland, 1999). Although when the susceptible parent was 'Keystone Resistant Giant no. 3', at least one dominant gene must be expressed for both root rot and foliar blight resistance besides a dominant gene required for foliar resistance and a different dominant gene required for root resistance (Walker and Bosland, 1999). However, the allelism tests were not determined. Resistance to Phytophthora fruit rot was controlled by the dominant gene Pfr in 'Waxy Globe' (Saini and Sharma, 1978).

Recently, six chromosomal regions (Phyto4.1, Phyto5.1, Phyto5.2, Phyto6.1, Phyto11.1, and Phyto12.1) were identified to be involved in one or more components of resistance to $P$. capsici (Thabuis et al., 2003). The Phyto5.2 QTL may be widely distributed in highly resistant accessions. SCAR marker D04.717 located in chromosome 5 was tightly linked with Phyto5.2 (Quirin et al., 2005).

\section{Resistance to anthracnose}

Resistance of C. annuum cv. Chungryong to Colletotrichum dematium was conferred by a dominant allele, Anrl, when the resistance was measured as a lesion with a diameter less than $18.1 \mathrm{~mm}$ (Park et al., 1992). The dominant genes were present for resistance to C. gloeosporioides: a single gene, Anr-2, in the accession BGH3077; and two genes, $A n r-3$ and $A n r-4$, in 'BGH2850' and 'BGH5085' (Fernandes and Ribeiro, 1998). One dominant gene, Anr-5, was responsible for the resistance to anthracnose incited by
C. capsici in the line ' $83-168$ ' at four days after inoculation (Lin et al., 2002). Allelism among $A n r$ gene series is unknown.

Voorrips and colleagues (2004) scored three resistance-related traits for anthracnose in an $\mathrm{F}_{2}$ population derived from the susceptible $C$. annuum cv. Jatilaba and the resistance $C$. chinense accession PRI95030. When fruits are inoculated with C. gloeosporioides, one main QTL, B1, was identified on all three traits, and three other QTLs were detected for overall lesion diameter and true lesion diameter, of which two also had an affect on infection frequency. When fruits are inoculated with $C$. capsici, the marker B1 was found for overall lesion diameter when marker G1 was used as cofactor in multiple QTL analysis. No significant QTLs were detected for two other traits.

\section{Resistance to ralstonia solanacearum}

The bacterial wilt resistance in the sweet pepper variety 'Mie-Midori' showed incomplete dominance, and at least two genes were involved in resistance (Matsunaga et al., 1998).

\section{Resistance to powdery mildew}

Leveillula taurica causes powdery mildew of pepper. The line $\mathrm{H}-\mathrm{V}-12$ immune to $L$. taurica races from Israel depends on three pairs of genes: $l m r-1, \operatorname{lm} r-2$, and $l m r-3$ (Shifriss et al., 1992). Daubeze and associates (1991) determined that at least three genes appeared to control resistance in the Ethiopian variety $\mathrm{H} 3$ to $L$. taurica. Later, Lefebvre and coworkers (2003) detected seven genomic regions, including additive QTLs and epistatic interactions contributing to the resistance of the variety $\mathrm{H} 3$.

\section{Resistance to root knot nematodes (Meloidogyne spp.)}

There are four economically important root-knot nematode species: Meloidogyne incognita (Kofoid and White) Chitwood, $M$. arenaria (Neal) Chitwood, M. javanica (Treub) Chitwood, and M. hapla Chitwood. As early as 1957, Hare (Fery and Harrison, 1990) identified a dominant gene, $N$, for resistance to $M$. incognita acrita in the $C$. annuum 'Santaka XS' line. Expression of the $N$ gene in bell pepper is modified and decreased at temperatures more than $28^{\circ} \mathrm{C}$ (Thies and Fery, 1998, 2002). Cytoplasmic factors are not involved in expression of $\mathrm{N}$-type resistance. The resistance of 'Carolina Hot' to $M$. incognita is conditioned by two genes: one dominant allelic to the dominant resistance gene $N$, and one recessive (Fery and Dukes, 1996). The resistance to $M$. incognita in $C$. chinense 'PA-426' is conditioned by a single dominant gene that is allelic to the dominant gene $N$ in the C. annuum 'Carolina Cayenne' (Fery and Thies, 1998). Resistance to $M$. arenaria race 1 in C. chinense lines PA-353 and PA-426 was conditioned by a single dominant gene that is allelic to a resistance gene in $C$. annuum 'Carolina Cayenne' (Fery and Thies, 2000). However, the allelism tests did not demonstrate conclusively that the $M$. arenaria race 1 resistance gene in $C$. chinense is the $N$ gene in $C$. annuum. Five main resistance dominant genes, $\mathrm{Me}-1$ to $\mathrm{Me}-5$, in $\mathrm{C}$. annuum line PM217 (PI 201234) and PM687 (PI 322719) were identified by Hendy et al. (1985) to confer resistance to Meloidogyne spp. (cited by Djian-Caporalino et al., 1999, and Souza-Sobrinho et al., 2002), all acting individually in a gene-for-gene interaction. The $M e-6$ gene specifically controlled resistance to $M$. arenaria and $M$. javanica (French population) in 'Yolo Wonder' (Djian-Caporalino, personal communication). Me-7 was found in CM 334, conferring a high level of resistance to $M$. arenaria, $M$. incognita, and M. javanica (Pegard et al., 2005). Two other loci, Mech-1 (in 'PM217') and Mech-2 (in 'CM334'), were identified to control the resistance to M. chitwoodi (DjianCaporalino et al., 2004). Among them, three dominant and thermostable loci with broadspectrum resistance ( $\mathrm{Me}-3, \mathrm{Me}-1$, and $\mathrm{Me}-7)$, Mech-1, and Mech-2 suppressed nematode reproduction (Djian-Caporalino et al., 1998, 1999, 2004). It appears that the $N$ gene and the $\mathrm{Me}-3$ gene both confer higher resistance than the $M e-1$ gene (Thies, 2004).

Fine mapping with AFLP markers flanked the resistance genes in coupling, and the nearest marker was located less than $2 \mathrm{cM}$ from Mech-1, $3 \mathrm{cM}$ from $\mathrm{Me}-1$, and $1 \mathrm{cM}$ from Mech-2 (Djian-Caporalino et al., 2004). The $M e-3$ nearest AFLP marker was $10.1 \mathrm{cM}$ from a RAPD marker Q04_0.3 and $2.7 \mathrm{cM}$ from RFLP marker CT135. $\mathrm{Me}-4$ was linked $10 \mathrm{cM}$ to $\mathrm{Me}-3$ (Djian-Caporalino et al., 2001). The genes $\mathrm{Me}-3, \mathrm{Me}-1, \mathrm{Me}-7, \mathrm{Mech}-1$, and Mech-2 are effectively different, but linked, and were all assigned to chromosome P9 (Djian-Caporalino et al., 2004).

\section{Bentazon herbicide tolerance}

The dominant gene $B z t$ is responsible for a high level of tolerance to the herbicide, bentazon, in C. annuum (Fery and Harrison, 1990; Wolff et al., 1992). A possible cytoplasmic involvement was present in the expression of the Bzt gene in the Santaka cultivar, and modifying genes affected the major gene, Bzt, controlling tolerance in the Bohemian Chilli cultivar.

\section{Conclusions and Perspectives}

Capsicum genetics have been extensively studied for nearly a century, and Capsicum breeding has benefited greatly from this knowledge. Some characteristics/traits appearing in the Capsicum genetic literature are not included in this list because incomplete inheritance data were provided. Many gene mutants or lines are not available. Hence, a need to have genetic stocks deposited and maintained in a repository for further research is warranted. Unfortunately, resources for a Capsicum Gene Stock Center are not available. Nevertheless, the Chile Pepper Institute at New Mexico State University maintains some of the mutants and makes them available to bonified Capsicum 
scientists. Future genetic exploration of Capsicum genes will include studying the allelic relationship among the similar genes, obtaining more gene mutants by the application of mutagens, developing a set of chromosome location lines using information from the tomato genome sequencing project, establishing linked molecular markers to genes, and characterizing gene function.

\section{Literature Cited}

Aniel Kumar, O., V. Anitha, K. Roseline Subhashini, and K.G. Raja Rao. 2001. Induced morphological mutations in Capsicum annuum L. Capsicum Eggplant Nswl. 20:72-75.

Arnedo-Andres, M., M.L. Arteaga, and R.G. Ortega. 1998. Response of 'Serrano Criollo de Morelos334' to PVY pathotypes. Proc. 10th Eucarpia Meeting on Genetics and Breeding of Capsicum and Eggplant, 7-11, Sept. 1998, Avignon, France, 105-109.

Arnedo-Andres, M., M.L. Arteaga, and R.G. Ortega. 2004. New genes related to PVY resistance in C. annuиm L. 'Serrano Criollo de Morelos-334'. Proc. 12th Eucarpia Meeting on Genetics and Breeding of Capsicum and Eggplant, 17-19 May 2004, Noordwijkerhout, the Netherlands. 134 138.

Arnedo-Andres, M., R.G. Ortega, M.L. Arteaga, and J.L. Hormaza. 2002. Development of RAPD and SCAR markers linked to the Pvr4 locus for resistance to PVY in pepper (Capsicum annuum L.). Theor. Appl. Genet. 105: 1067-1074.

Arroyo, R., M.J. Soto, J.M. Martinez-Zapater, and F. Ponz. 1996. Impaired cell to cell movement of potato virus $\mathrm{Y}$ in pepper plants carrying the ya (pvr21) resistance gene. Mol. Plant Microbe Interact. 9:314-318.

Arumuganathan, K. and E.D. Earle. 1991. Nuclear DNA content of some important plant species. Plant Mol. Biol. Rep. 9:208-218.

Ayme, V., O. Pierrugus, S. Souche, G. Nemouchi, C. Caranta, M. Jacquemond, J. Chadoeuf, A. Palloix, and B. Moury. 2004. PVR evolution toward virulence to the resistance conferred by $p v r 2^{3}$ in pepper and consequences for its durability. Proc. 12th Eucarpia Meeting on Genetics and Breeding of Capsicum and Eggplant, 17-19 May 2004, Noordwijkerhout, the Netherlands. 139-146.

Belletti, P., C. Marzachi, and S. Lanteri. 1998. Flow cytometric measurement of nuclear DNA content in Capsicum (Solanaceae). Plant Syst. Evol. 209:85-91.

Ben Chaim, A., I. Paran, R.C. Grube, M.K. Jahn, R. van Wijk, and J. Peleman. 2001. QTL mapping of fruit-related traits in pepper (Capsicum annuum). Theor. Appl. Genet. 102:1016-1028.

Ben Chaim, A., Y. Borovsky, W. De Jong, and I. Paran. 2003. Linkage of the $A$ locus for the presence of anthocyanin and $f_{s} 10.1$, a major fruit-shape QTL in pepper. Theor. Appl. Genet. 106:889-894.

Bergh, B.O. and L.F. Lippert. 1964. Six new mutant genes in the pepper, Capsicum annuum. L. J. Hered. 55:296-300.

Bergh, B.O. and L.F. Lippert. 1965. A gene difference that affects female fertility in Capsicum annuum L. Amer. Nat. 99:159-166.

Blum, E., K. Liu, M. Mazourek, E.Y. Yoo, M. Jahn, and I. Paran. 2002. Molecular mapping of the $C$ locus for presence of pungency in Capsicum. Genome. 45:702-705.

Boiteux, L.S. 1995. Allelic relationships between genes for resistance to tomato spotted wilt tospovirus in Capsicum chinense. Theor. Appl. Genet. 90:146-149.

Boiteux, L.S., F.P. Cupertino, C. Silva, A.N. Dusi, D.C. Monte-Neshich, R.A.A. van der Vlugt, and M.E.N. Fonseca. 1996. Resistance to potato virus Y (pathotype 1-2) in Capsicum annuum and $C$. chinense is controlled by two independent major genes. Euphytica. 87:53-58.

Boiteux, L.S. and A.C. de Avila. 1994. Inheritance of a resistance specific to tomato spotted wilt tospovirus in Capsicum chinense PI 159236. Euphytica. 75:139-142.

Bosland, P.W. 1992. Chiles: A diverse crop. Horttechnology. 2:6-10.

Bosland, P.W. 2002. Inheritance of a novel flaccid mutant in Capsicum annuum. J. Hered. 93:380382.

Bosland, P.W. and E.J. Votava. 2000. Peppers: Vegetable and spice Capsicums. CABI Publishing, New York.

Boswell, V.R. 1937. Improvement and genetics of tomatoes, peppers, and eggplant, p. 176-206. Yearbook of agriculture. In: U.S. Government Printing Office, Washington, D.C.

Boukema, I.W. 1980. Allelism of genes controlling resistance to TMV in Capsicum L. Euphytica. 29:433-439.

Boukema, I.W. 1984. Resistance to TMV in Capsicum chacoense Hunz. is governed by an allele of the L-locus. Capsicum Eggplant Nswl. 3:47-48.

Boukema, I.W., K. Jansen, and K. Hofman. 1980. Strains of TMV and genes for resistance in Capsicum. Proc. Capsicum working group meeting. Wageningen, the Netherlands, 44-48.

Caranta, C., V. Lefebvre, and A. Palloix. 1997a. Polygenic resistance of pepper to potyviruses consists of a combination of isolate-specific and broad-spectrum quantitative trait loci. Mol. Plant Microbe Interact. 10:872-878.

Caranta, C. and A. Palloix. 1996. Both common and specific genetic factors are involved in polygenic resistance to several potyviruses. Theor. Appl. Genet. 92:15-20.

Caranta, C., A. Palloix, G. Gebre Selassie, V. Lefebvre, B. Moury, and A.M. Daubeze. 1996. A complementation between two genes originating from susceptible Capsicum anпиит L. lines confers a new and complete resistance to pepper veinal mottle virus. Phytopathology. 86:739-743

Caranta, C., A. Palloix, V. Lefebvre, and A.M. Daubèze. 1997b. QTLs for a component of partial resistance to cucumber mosaic virus in pepper: restriction of virus installation in hostcells. Theor. Appl. Genet. 94:431-438.

Caranta, C., S. Pflieger, V. Lefebvre, A.M. Daubèze, A. Thabuis, and A. Palloix. 2002. QTLs involved in the restriction of cucumber mosaic virus (CMV) long-distance movement in pepper. Theor. Appl. Genet. 104:586-591.

Caranta, C., A. Thabuis, and A. Palloix. 1999. Development of a CAPS marker for the Pvr4 locus: A tool for pyramiding potyvirus resistance genes in pepper. Genome. 42:1111-1116.

Caranta, C., A. Thabuis, A. Romero, A.M. Daubeze, A. Blattes, G. Nemouchi, J.C. Chauvet, F. Ponz, and A. Palloix. 1998. Potyvirus resistance in pepper: AFLP mapping and characterization of the resistance mechanisms controlled by the Pvr4 and pvr5 genes. Proc. 10th Eucarpia Meeting on Genetics and Breeding of Capsicum and Eggplant, 7-11 Sept. 1998, Avignon, France. 121-124.

CENL Committee for Capsicum Gene Nomenclature. 1994. Rules for gene nomenclature of Capsicum. Capsicum Eggplant Nswl. 13:13-14.
Chalukova, M., S. Daskolov, E. Lukarska, and D. Baralieva. 1993. Beta-orange mutant in pepper (Capsicum annuum L.). Capsicum Eggplant Nswl. 12:57-58.

Choi, K.S., D.H. Pae, Y.H. Om, and C.H. Lee. 1988. Studies on the breeding of disease resistance in red pepper (Capsicum annuum L.). 4. Breeding of Jangsugochu, a multi-disease resistant variety and the mode of inheritance of resistance to Phytophthora capsici and TMV. Research Reports of the Rural Development Administration, Horticulture. 30:1-8.

Cook, A.A. 1960. Genetics of resistance in Capsicum annuиm to two virus diseases. Phytopathology. 50:364-367.

Cook, A.A. 1961a. A mutation for resistance to potato virus $\mathrm{Y}$ in pepper. Phytopathology. 51:550-552.

Cook, A.A. 1961b. Inheritance of mutant-1 phenotype in the pepper. J. Hered. 52:154-158.

Cook, A.A. 1962. Studies of a foliage variegation in pepper. Proc. Amer. Soc. Hort. Sci. 81:390-395.

Cook, A.A. 1963. Genetics of response in pepper to three strains of potato virus Y. Phytopathology. 53:720-722.

Cook, A.A. 1982. Disease resistance studies and new releases from Florida. Capsicum Nswl. 1:43.

Cook, A.A. and C.W. Anderson. 1959. Multiple virus disease resistance in a strain of Capsicum annuum. Phytopathology. 49:198-201.

Cook, A.A. and Y.G. Guevara. 1984. Hypersensitivity in Capsicum chacoense to race 1 of pepper. Plant disease 68:329-330.

Cook, A.A. and R.E. Stall. 1963. Inheritance of resistance in pepper to bacterial spot. Phytopathology. 53:1060-1062.

Cristinzio, G.V. Zema, A. Errico and F. Saccardo. 1992. Introduction of resistance genes to Phytophthora capsici into cultivar of Capsicum annuum 'Friariello'. Proc. 8th Meeting on Genetics and Breeding on Capsicum and Eggplant, Rome, Italy. 189-193. 7-10 Sept. 1992.

Csillery, G. 1980a. Gene mapping of the pepper needs more initiatives (contribution to the gene list). Proc. 4th Eucarpia Meeting of Capsicum Working Group, 17-19 May 1980, Wageningen, the Netherlands. 5-9.

Csillery, G. 1980b. Self-eliminating genes suitable for the purpose of hybrid seed production. Proc. 4th Eucarpia Meeting of Capsicum Working Group, 17-19 May 1980, Wageningen, the Netherlands. 27-28.

Csillery, G. 1983. New Capsicum mutants found on seedling, growth type, leaf, flower and fruit. Proc. 5th Eucarpia Meeting of Capsicum and Eggplant Working Group, 4-7 July 1983, Plovdiv. 127-130.

Csillery, G. 1984. Linkage between an 'anthocyaninless' and a 'mosaic' gene. Capsicum Eggplant Nswl. 3:52-53.

Csillery, G. 1985. Abnormal segregation ratio in a 'lutescens' hybrid in Capsicum baccatum. Capsicum Eggplant Nswl. 4:43.

Csillery, G., E. Szarka, E. Sardi, J. Mityko, J. Kapitany, B. Nagy, and J. Szarka. 2004. The unity of plant defense: Genetics, breeding and physiology. Proc. 12th Eucarpia Meeting on Genetics and Breeding of Capsicum and Eggplant, 17-19 May 2004, Noordwijkerhout, the Netherlands. 147-153.

Curtis, L.C. and J. Scarchuck. 1948. Seedless peppers. J. Hered. 39:159-160.

Daskalov, S. 1968. A male sterile (Capsicum annuum L.) mutant. Theor. Appl. Genet. 38:370-372.

Daskalov, S. 1971. Two new male sterile mutants by pepper (C. апnum). C.R. Acad. Sci. Agr. Bulg. 4:291-294. 
Daskalov, S. 1973a. Gene list for the pepper. Genet. Plant Breeding. 6:401-408.

Daskalov, S. 1973b. Investigation of induced mutants in Capsicum annuum L. III. Mutants in the variety Zlaten Medal. Genet. Plant Breeding. 6:419-429.

Daskalov, S. 1974. Investigation on induced mutants in sweet pepper (Capsicum annuиm L.). Proc. 1st Meeting of the Capsicum Breeding and Genetics, Budapest, Hungary. 81-90. 1-4 July 1974.

Daskalov, S. 1987. Investigations on mutagenesis and heterosis in pepper (Capsicum annuum L.). D.Sc. Thesis [in Bulgarian].

Daskalov, S., M. Chalukova, D. Baralieva, and E. Lukarska. 1995. Biochemical investigations of an induced beta-orange mutant in sweet pepper (Capsicum annuum L.) and developing varieties with increased beta-carotene content. Proc. 9th Eucarpia Meeting on Genetics and Breeding of Capsicum and Eggplant, 21-25 Aug. 1995. Budapest, Hungary. 24-27.

Daskalov, S. and L. Mihailov. 1988. A new method for hybrid seed production based on cytoplasmic male sterility combined with a lethal gene and a female sterile pollenizer in Capsicum annuum L. Theor. Appl. Genet. 76:530-532.

Daskalov, S. and J.M. Poulos. 1994. Updated Capsicum gene list. Capsicum Eggplant Nswl. 13:16-26.

Daubeze, A.M., A. Palloix, and E. Pochard. 1990. Resistance of androgenic autodiploid lines of pepper to Phytophthora capsici and tobacco mosaic virus under high temperature. Capsicum Nswl. 8/9:47-48.

Daubeze, A.M., E. Pochard, and A. Palloix. 1989 Inheritance of resistance to Leveillula taurica and relation to other phenotypic characters in the haploidiploid progeny issued from an African pepper line. Proc. 7th Eucarpia Meeting on Genetics and Breeding of Capsicum and Eggplant, 27-30 June 1989, Palanka, Yugoslavia, p. 229-232.

Deom, C.M., J.F. Murphy, and O.R. Paguio. 1997. Resistance to tobacco etch virus in Capsicum annuum: Inhibition of virus RNA accumulation. Mol. Plant Microbe Interact. 10:917-921.

Deshpande, R.B. 1933. Studies in Indian chillies. 3. The inheritance of some characters in Capsicum annuum L. Indian Jour. Agr. Sci. 3:219300.

Deshpande, R.B. 1935. Studies in Indian chillies. 4. Inheritance of pungency in Capsicum annuum L. Indian J. Agr. Sci. 5:513-516.

Deshpande, A.A., C.S. Pathak, and D.P. Singh. 1983. Types of male sterility in chilli pepper (Capsicum spp.). Capsicum Nswl. 2:97-98.

Djian-Caporalino, C., F. Berthou, A. Fazari, V. Lefebvre, A. Palloix, A. Pegard, and L. Pijarowski. 2004. Genetic, cytological and molecular bases of the resistance to root-knot nematodes (Meloidogyne spp.) in pepper (Capsicum annuum L.). Proc. 12th Eucarpia Meeting on Genetics and Breeding of Capsicum and Eggplant, 17-19 May 2004, Noordwijkerhout, the Netherlands. 180.

Djian-Caporalino, C., L. Pijarowski, A. Fazari, M. Samson, L. Gaveau, C. O’Byrne, V. Lefebvre, C. Caranta, A. Palloix, and P. Abad. 2001. High-resolution genetic mapping of the pepper (Capsicum annuum L.) resistance loci $\mathrm{Me} 3$ and $\mathrm{Me} 4$ conferring heat-stable resistance to rootknot nematode (Meloidogyne spp.). Theor. Appl. Genet. 103:592-600.

Djian-Caporalono, C., L. Pijarowski, A. Januel, V. Lefebvre, C. Caranta, J.C. Chauvet, A. Blattes, A. Palloix, A. Dalmasso, and P. Abad. 1998. Characterising and fine mapping of the $\mathrm{Me} 3$ gene conferring heat-stable resistance to rootknot nematodes (Meloidogyne spp.) in pepper (Capsicum annuum L.) using AFLPs. Proc. 10th Eucarpia Meeting on Genetics and Breeding of Capsicum and Eggplant, 7-11 Sept. 1998. Avignon, France. 125-128.

Djian-Caporalino, C., L. Pijarowski, A. Januel, V. Lefebvre, A. Daubèze, A. Palloix, A. Dalmasso, and P. Abad. 1999. Spectrum of resistance to root-knot nematode and inheritance of heatstable resistance in pepper (Capsicum annuum L.). Theor. Appl. Genet. 99:496-502.

Dogimont, C., A. Palloix, A.M. Daubeze, G. Marchoux, K. Gebre Selassie, and E. Pochard. 1996. Genetics of broad spectrum resistance to potyviruses in haplodiploid progenies of pepper (Capsicum annuum). Euphytica. 88:231-239.

Fan, Y. and J. Guo. 1994. Breeding and application aspect of male sterile lines in sweet pepper, p. 256-259. In: G. Dong and L. Meng (eds.). Advances in horticultural science. China Agriculture Press, Beijing, China. [in Chinese].

Fan, Y., Y. Liu, and L. Yan. 2004. Breeding and application of male sterile lines in sweet pepper. J. Hebei Agr. Sci. 8:26-29 [in Chinese].

FAO. 2005. Agricultural statistics for 2005. Food Agr. Org. United Nations, Rome.

Fernandes, and R. de L.D. Ribeiro. 1998. Mode of inheritance of resisitance in Capsicum annuum accessions to Colletotrichum gloeosporioides. Proc. 10th Eucarpia Meeting on Genetics and Breeding of Capsicum and Eggplant, 7-11 Sept. 1998. Avignon, France. 170.

Fery, R.L. and P.D. Dukes. 1996. The inheritance of resistance to the southern root-knot nematode in 'Carolina Hot' cayenne pepper. J. Amer. Soc. Hort. Sci. 121:1024-1027.

Fery, R.L. and H.F. Harrison Jr., 1990. Inheritance and assessment of bentazon herbicide tolerance in 'Santaka' pepper. J. Amer. Soc. Hort. Sci. 115:854-857.

Fery, R.L. and J.A. Thies. 1998. Genetic analysis of resistance to the southern root-knot nematode in Capsicum chinense Jacq. J. Amer. Soc. Hort. Sci. 123:1008-1011.

Fery, R.L. and J.A. Thies. 2000. Inheritance of resistance to the peanut root-knot nematode in Capsicum chinense. J. Amer. Soc. Hort. Sci. 125:615-618.

Gebre Selassie, K.E., G. Marchoux, and E. Pochard. 1983. Biological and serological characterization of potato virus $\mathrm{Y}$ strains affecting peppers and other related strains. Capsicum Nswl. 2:134-136.

Gil Ortega, R. and M.L. Arteaga. 1988. Response of pepper to two Spanish isolates of CMV Capsicum Nswl. 7:65-66.

Gil Ortega, R., C. Palazon Español, and J. Cuartero Zueco. 1991. Genetics of resistance to Phytophthora capsici in the pepper line 'SCM-334'. Plant Breed. 107:50-55.

Gil Ortega, R., C. Palazon Español, and J. Cuartero Zueco. 1992. Genetic relationships among four pepper genotypes resistant to Phytophthora capsici. Plant Breed. 108:118-125.

Gopalakrishnan, T.R., P.K. Gopalakrishnan, and K.V. Peter. 1989. Inheritance of clusterness and fruit orientation in chilli (Capsicum annuum L.). Indian J. Genetics 49:219-222.

Green, S.K. and J.S. Kim. 1991. Characteristics and control of viruses infecting peppers: A literature review. Technical bulletin no. 18. Asian Vegetable Research and Development Center, Taiwan.

Greenleaf, W.H. 1952. Inheritance of pungency and of the deciduous fruit character in peppers
(Capsicum annuum). Proc. Assoc. South. Agr. Workers. 49:110-111.

Greenleaf, W.H. 1956. Inheritance of resistance to tobacco etch virus in Capsicum frutescens and in Capsicum annuum. Phytopathology. 46:371-375.

Greenleaf, W.H. 1986. Pepper breeding, p. 67-134. In: Mark J. Bassett (ed.). Breeding vegetable crops. AVI Publishing, Westport, Conn.

Greenleaf, W.H. and W.H. Hearn. 1976. A round leaf mutant in 'Bighart' pimiento pepper (Capsicum annuиm). HortScience. 11:463464.

Grube, R.C., J.R. Blauth, M. Arnedo-Andres, C. Caranta, and M.K. Jahn. 2000. Identification and comparative mapping of a dominant potyvirus resistance gene cluster in Capsicum. Theor. Appl. Genet. 101:852-859.

Hagiwara, T. and Y. Oomura. 1947. On linkage in Capsicum annuum. Jap. Jour. Genet. Supp. 1:86-96.

Hare, W.W. 1957. Inheritance to root-knot nematodes in pepper. Phytopathology. 47:455-459.

Hendy, H., E. Pochard, and A. Dalmasso. 1985. Inheritance of resistance to Meloidogyne Chitwood (Tylenchida in two lines of Capsicum annuиm $\mathrm{L}$.: homozygous progenies obtained by androgenesis. Agronomie: sciences des productions vegetales et de l'environnement. 5:93-99 (in French).

Hernandez, H.H. and P.G. Smith. 1985. Inheritance of mature fruit color in Capsicum annuum L.J. Hered. 76:211-213.

Herison, C., Rustikawati, and Sudarsono. 2004. Genetics of resistance against cucumber mosaic virus (CMV) in hot pepper (Capsicum annuum L.). Capsicum Eggplant Nswl. 23:113-116.

Hibberd, A.M., M.J. Bassett, and R.E. Stall. 1987. Allelism tests of three dominant genes for hypersensitive resistance to bacterial spot of pepper. Phytopathology. 77:1304-1307.

Holmes, F.O. 1934. Inheritance of ability to localize tobacco mosaic virus. Phytopathology. 24:984-1002.

Holmes, F.O. 1937. Inheritance of resistance to tobacco mosaic disease in the pepper. Phytopathology. 27:637-642.

Huh, J.H., B.C. Kang, S.H. Nahm, S. Kim, K.S. Ha, M.H. Lee, and B.D. Kim. 2001. A candidate gene approach identified phytoene synthase as the locus for mature fruit color in red pepper (Capsicum spp.). Theor. Appl. Genet. 102:524530.

Hurtado-Hernandez, H. and P.G. Smith. 1985. Inheritance of mature fruit color in Capsicum annuum L. J. Hered. 76:211-213.

Inai, S., K. Ishikawa, O. Nunomura, and $\mathrm{H}$. Ikehashi. 1993. Genetic analysis of stunted growth by nuclear-cytoplasmic interaction in interspecific hybrids of Capsicum by using RAPD markers. Theor. Appl. Genet. 87:416422.

Ishikawa, K., T. Janos, and O. Nunomura. 1998. Inheritance of the fruit shape at the apex and the peduncle attachment of pepper. Capsicum Eggplant Nswl. 17:30-33.

Jahn, M., I. Paran, K. Hoffmann, E.R. Radwanski, K.D. Livingstone, R.C. Grube, E. Aftergoot, M. Lapidot, and J. Moyer. 2000. Genetic mapping of the $T s w$ locus for resistance to the tospovirus tomato spotted wilt virus in Capsicum spp. and its relationship to the $S w-5$ gene for resistance to the same pathogen in tomato. Mol. Plant Microbe Interact. 13:673-682.

Jones, J.B., G.V. Minsavage, P.D. Roberts, R.R. Johnson, C.S. Kousik, S. Subramanian, and 
R.E. Stall. 2002. A non-hypersensitive resistance in pepper to the bacterial spot pathogen is associated with two recessive genes. Phytopathology. 92:273-277.

Kang, B.C., I. Yeam, J.D. Frantz, J.F. Murphy, and M.M. Jahn. 2005. The pvrl locus in pepper encodes a translation initiation factor eIF4E that interacts with tobacco etch virus VPg. Plant J. 42:392-405.

Kim, K.T., H.S. Choi, H.J. Kim, D.H. Pae, J.Y. Yoon, and B.D. Kim. 2001. Development of DNA markers linked to bacterial leaf spot resistance of chilli. Acta Hort. 546:597-601.

Kim, B.S. and R.W. Hartmann. 1985. Inheritance of a gene $(B s 3)$ conferring hypersensitive resistance to Xanthomonas campestris pv. vesicatoria in pepper (Capsicum annuum). Plant Dis. 69:233-235.

Kim, B.S. and J.M. Hur. 1990. Inheritance of resistance to bacterial spot and to Phytophthora blight in peppers. J. Korean Society for Horticultural Science 31:350-357.

Kim, D.H. and B.D. Kim. 2005. Development of SCAR markers for early identification of cytoplasmic male sterility genotype in chili pepper (Capsicum annuum L.). Mol. Cells. 20:416-422.

Kyle, M.M. and A. Palloix. 1997. Proposed revision of nomenclature for potyvirusresistance gene in Capsicum. Euphytica. 97:183-188.

Lefebvre, V., A.M. Daubeze, J. Rouppe van der Voort, J. Peleman, M. Bardin, and A. Palloix. 2003. QTLs for resisitance to powdery mildew in pepper under natural and artificial infections. Theor. Appl. Genet. 107:661-666.

Lefebvre, V., M. Kuntz, B. Camara, and A. Palloix. 1998. The capsanthin capsorubin synthase gene: A candidate gene for the y locus controlling the red fruit color in pepper. Plant Mol. Biol. 36:785-789

Lefebvre, V., A. Palloix, C. Caranta, and E. Pochard. 1995. Construction of an intraspecific integrated linkage map of pepper using molecular markers and doubled haploid progenies. Genome. 38:112-121.

Lin, Q., C. Kanchana-Udomkarn, T. Jaunet, and O. Mongkolporn. 2002. Inheritance of resistance to pepper anthracnose caused by Colletotrichum capsici. Capsicum Eggplant Nswl. 21:85-88.

Lippert, L.F., B.O. Bergh, and A.A. Cook. 1964. Three variegated seedling mutants in the pepper. J. Hered. 55:79-83.

Lippert, L.F., B.O. Bergh, and P.G. Smith. 1965. Gene list for the pepper. J. Hered. 56:30-34.

Lippert, L.F., P.G. Smith, and B.O. Bergh. 1966. Cytogenetics of the vegetable crops Garden pepper, Capsicum sp. Bot. Rev. 32:24-55.

Loaiza-Figueroa, F. and S.D. Tanksley. 1988. Genetics of a second locus determining pungency in chili peppers (Capsicum). J. Hered. 79:314-315.

Luis Arteaga, M., M. Arnedo Andres, and R. Gil Ortega. 1997. New potato virus Y pathotype in pepper. Capsicum Eggplant Nswl. 16:85-86.

Luis Arteaga, M., and R. Gil Ortega. 1998. Low temperature can also break Capsicum chinense resistance to tomato spotted wilt virus. Proc. 10th Eucarpia Meeting on Genetics and Breeding of Capsicum and Eggplant, 7-11 Sept. 1998, Avignon, France. 145-147.

Ma, Z., S. Yan, X. Luo, X. Shen, X. Wang, Z. Hu, H. Hao, and W. Wei. 2001. Breeding and genetic analysis of yellow-green seedling mutant in pepper. Changjiang Veg. 4:31-32. [in Chinese].

Martin, J.A. and J.H. Crawford. 1951. Several types of sterility in Capsicum frutescens. Proc. Amer. Soc. Hort. Sci. 57:335-338.
Matsunaga, H., T. Saito, M. Hirai, T. Nunome, and T. Yoshida. 2003. DNA markers linked to pepper mild mottle virus (PMMoV) resistance locus (L4) in Capsicum. J. Jpn. Soc. Hort. Sci. $72: 218-220$

Matsunaga, H., T. Sato, and S. Monma. 1998. Inheritance of bacterial wilt resistance in the sweet pepper cv. Mie-Midori. Proc. 10th Eucarpia Meeting on Genetics and Breeding of Capsicum and Eggplant, 7-11 Sept. 1998, Avignon, France. 172.

McCammon, K.R. and S. Honma. 1984. Genetics of the "umbrella" branching habit in Capsicum annuum L. Theor. Appl. Genet. 68:541-545.

Meshram, L.D. and M.N. Narkhede. 1982. Natural male sterile mutant in hot chilli (Capsicum annuum L.). Euphytica. 31:1003-1005.

Meshram, L.D., R.V. Choudhari, B.Y. Kukade, and M.W. Marawar. 1992. Functional male sterility in hot chilli (Capsicum annuum L.). Proc. 8th Eucarpia Meeting on Genetics and Breeding on Capsicum and Eggplant, Rome, Italy. 7-10 Sept. 1992. 61-65.

Miller, J.C. and Z.M. Fineman. 1938. A genetic study of some qualitative and quantitative characters of the genus. Capsicum. Proc. Amer. Soc. Hort. Sci. 35:544-550.

Minsavage, G.V., D. Dahlbeck, M.C. Whalen, B Kearney, U. Bonas, B.J. Staskawicz, and R.E. Stall. 1990. Gene-for-gene relationships specifying disease resistance in Xanthomonascampestris pv. vesicatoria-pepper interactions. Mol. Plant Microbe Interact. 3:41-47.

Moury, B., C. Morel, E. Johansen, L. Guilbaud, S. Souche, V. Ayme, C. Caranta, A. Palloix, and M. Jacquemond. 2004. Mutations in potato virus $\mathrm{Y}$ genome-linked protein determine virulence toward recessive resistances in Capsicum annuum and Lycopersicon hirsutum. Mol. Plant Microbe Interact. 17:322-329.

Moury, B., A. Palloix, K.G. Selassie, and G. Marchoux. 1997. Hypersensitive resistance to tomato spotted wilt virus in three Capsicum chinense accessions is controlled by a single gene and is overcome by virulent strains. Euphytica. 94:45-52.

Moury, B., S. Pflieger, A. Blattes, V. Lefebvre, and A. Palloix. 2000. A CAPS marker to assist selection of tomato spotted wilt virus (TSWV) resistance in pepper. Genome. 43:137-142.

Murphy, J.F., J.R. Blauth, K.D. Livingstone, V.K Lackney, and M.K. Jahn. 1998. Genetic mapping of the pvrl locus in Capsicum spp. and evidence that distinct potyvirus resistance loci control responses that differ at the whole plant and cellular levels. Mol. Plant Microbe. Interact. 11:943-951.

Murphy, J.F. and M.M. Kyle. 1995. Alleviation of restricted systemic spread of pepper mottle potyvirus in Capsicum annuum cv. Avelar by coinfection with a cucumovirus. Phytopathology. 85:561-566.

Nono-Wondim, R., K. Gebre-Selassie, A. Palloix, E. Pochard, and G. Marchoux. 1993. Study of multiplication of cucumber mosaic virus in susceptible and resistant Capsicum annuиm lines. Ann. Appl. Biol. 122:49-56.

Novac, F., J. Betlach, and J. Dubovshi. 1971. Cytoplasmic male sterility in sweet pepper (Capsicum annuum L.) 1. Phenotype and inheritance of male sterile character. Z. Pflanzenzuecht. 65:129-140.

Odland, M.L. 1960. Inheritance of flower color in Capsicum annuum L. Proc. Amer. Soc. Hort. Sci. 76:475-481.

Odland, M.L. and A.M. Porter. 1938. Inheritance of the immature fruit color of peppers. Proc. Amer. Soc. Hort. Sci. 36:647-651.
Palloix, A. 1992. Disease of pepper and perspectives for genetic control. Proc. 8th Eucarpia Meeting on Genetics and Breeding on Capsicum and Eggplant, Rome, Italy. 7-10 Sept. 1992. 120-126.

Panda, R.C., O.A. Kumar, and K.G. Raja Rao. 1987. Desynaptic mutant in chili pepper. J. Hered. 78:101-104.

Paran, I., J.R. van der Voort, V. Lefebvre, M. Jahn, L. Landry, M. van Schriek, B. Tanyolac, C. Caranta, A. Ben Chaim, K. Livingstone, A. Palloix, and J. Peleman. 2004. An integrated genetic linkage map of pepper (Capsicum spp.). Mol. Breed. 13:251-261.

Park, H.K., B.S. Kim, and W.S. Lee. 1990. Inheritance of resistance to anthracnose (Colletotrichum spp.) in pepper (Capsicum annuum L.). II. Genetics analysis of resistance to Colletotrichum dematium. J. Korean Society for Horticultural Science 31:207-212.

Pasko, P., M. Luis Arteaga, and R.G. Ortega. 1992. Different kinds of reactions to PVY-1-2 in Capsicum annuum L. cv. 'SCM-334'. Proc. 8th Eucarpia Meeting on Genetics and Breeding of Capsicum and Eggplant, Rome, Italy. $7-$ 10 Sept. 1992. 153-156.

Pasko, P., R.G. Ortega, and M.L. Arteaga. 1996. Resistance to potato virus $\mathrm{Y}$ in peppers. Capsicum Eggplant Nswl. 15:11-27.

Pathak, C.S., D.P. Singh, and A.A. Deshpande. 1983a. Closed flower mutant in Capsicum annuum L. Capsicum Nswl. 2:99-100.

Pathak, C.S., D.P. Singh, and A.A. Deshpande. 1983b. Male and female sterility in chilli pepper (Capsicum annuum L.). Capsicum Nswl. 2:95-96.

Pathak, C.S., D.P. Singh, and A.A. Deshpande. 1983c. Parthenocarpy in chillies (Capsicum annuит L.). Capsicum Nswl. 2:102-103.

Pathak, C.S., A.A. Deshpande, and D.P. Singh. 1985. Non-flowering mutant in chillies (Capsicum annuum L.). Capsicum Nswl. 4:41-42.

Pegard, A., G. Brizzard, A. Fazari, O. Soucaze, P. Abad, and C. Djian-Caporalino. 2005. Histological characterization of resistance to different root-knot nematode species related to phenolics accumulation in Capsicum annuum. Phytopathology. 95:158-165.

Peterson, P.A. 1958. Cytoplasmically inherited male sterility in Capsicum. Amer. Nat. 92: 111-119.

Peterson, P.A. 1959. Linkage of fruit shape and color genes in Capsicum. Genetics. 44:407-419.

Pierre, M., L. Noel, T. Lahaye, A. Ballvora, J. Veuskens, M. Ganal, and U. Bonas. 2000. High-resolution genetic mapping of the pepper resistance locus $B s 3$ governing recognition of the Xanthomonas campestris pv. vesicatora AvrBs3 protein. Theor. Appl. Genet. 101: 255-263.

Pochard, E. 982. A major gene with quantitative effect on two different viruses, CMV and TMV. Capsicum Nswl. 1:56-58.

Pochard, E. and A.M. Daubeze. 1989. Progressive construction of a polygenic resistance to cucumber mosaic virus in the pepper. Proc. 7th Eucarpia Meeting on Genetics and Breeding of Capsicum and Eggplant, 27-30 June 1989, Palanka, Yugoslavia. 187-192.

Pochard, E., R. Dumas de Vaulx, and A. Florent. 1983. Linkage between partial resistance to CMV and susceptibility to TMV in the line 'Perennial': Analysis on androgenetic homozygous lines. Capsicum Nswl. 2:32-33.

Popovsky, S. and I. Paran. 2000. Molecular genetics of the y locus in pepper: Its relation to capsanthin-capsorubin synthase and to fruit color. Theor. Appl. Genet. 101:86-89. 
Poulos, J.M., F.J.B. Reifschneider, and W.R. Coffman. 1991. Heritability and gain from selection for quantitative resistance to Xanthomonas campestris pv. vesicatoria in Capsicum annuum L. Euphytica. 56:161-167.

Poulos, J.M., F.J.B. Reifschneider, and W.R. Coffman. 1992. Inheritance of quantitative components of resistance to Xanthomonas campestris pv. vesicatoria in pepper line 'CNPH703'. Proc. 8th Eucarpia Meeting on Genetics and Breeding on Capsicum and Eggplant, Rome, Italy. $7-$ 10 Sept., 1992. 166-171.

Prince, J.P., E. Pochard, and S.D. Tanksley. 1993. Construction of a molecular linkage map of pepper and a comparison of synteny with tomato. Genome. 36:404-417.

Prolaram, B., T. Christopher, and Subhash. 1990. Seedless fruit mutant in Capsicum. Capsicum Nswl. 89:45-46.

Quirin, E.A., E.A. Ogundiwin, J.P. Prince, M. Mazourek, M.O. Briggs, T.S. Chlanda, K.T. Kim, M. Falise, B.C. Kang, and M.M. Jahn. 2005. Development of sequence characterized amplified region (SCAR) primers for the detection of Phyto.5.2, a major QTL for resistance to Phytophthora capsici Leon. in pepper. Theor. Appl. Genet. 110:605-612.

Rao, G.U. and I. Paran. 2003. Polygalacturonase: A candidate gene for the soft flesh and deciduous fruit mutation in Capsicum. Plant Mol. Biol. 51:135-141.

Reifschneider, F.J.B., L.S. Boiteux, P.T. Della Vecchia, J.M. Poulos, and N. Kuroda. 1992. Inheritance of adult-plant resistance to Phytophthora capsici in pepper. Euphytica. 62:45-49.

Restaino, F. 1989. New dwarf pepper (Capsicum annuит L.) cv. developed through mutation induction. Proc. 7th Eucarpia Meeting on Genetics and Breeding of Capsicum and Eggplant, $27-$ 30 June 1989, Palanka, Yugoslavia. 55-59.

Ruffel, S., M.H. Dussault, M.L. Lesage, A. Moretti, A. Palloix, M.C. Daunay, B. Moury, A. Bendahmane, C. Robaglia, and C. Caranta. 2004. Involvement of the eukaryotic translation initiation factor eIF4E in Solanacean-Potyvirus interactions. Proc. 12th Eucarpia Meeting on Genetics and Breeding of Capsicum and Eggplant. 17-19 May 2004. Noordwijkerhout, the Netherlands. 167-170.

Ruffel, S., M.H. Dussault, A. Palloix, B. Moury, A. Bendahmane, C. Robaglia, and C. Caranta. 2002. A natural recessive resistance gene against potato virus $\mathrm{Y}$ in pepper corresponds to the eukaryotic initiation factor 4E (eIF4E). Plant J. 32:1067-1075.

Sahin, F. and S.A. Miller. 1997. A source of resistance in Capsicum spp. accessions to pepper race 6 of Xanthomonas campestris pv. vesicatoria [abstract]. Phytopathology. 87:S84.

Sahin, F. and S.A. Miller. 1998. Resistance in Capsicum pubescens to Xanthomonas campestris pv. vesicatoria pepper race 6. Plant Dis. 82:794-799.

Saini, S.S. and P.P. Sharma. 1978. Inheritance of resistance to fruit rot (Phytophthora capsici Leon.) and induction of resistance in bell pepper (Capsicum annuum L.). Euphytica. 27:721-723.

Saito, T., T. Yoshida, A. Saito, and T. Yamada. 2004. Genetics of resistance to cucumber mosaic virus (CMV) in sweet pepper (Capsicum annuиm L.). Proc. 12th Eucarpia Meeting on Genetics and Breeding of Capsicum and Eggplant. 17-19 May, 2004. Noordwijkerhout, the Netherlands. 191.

Salamon, P., G. Venczel, L. Zatykó, and Z. Sági. 2001. Studies on the Tobamovirus resistance of the pepper (Capsicum annuum L.) cultivar Greygo. Intl. J. Hort. Sci. 7:71-75.

Shifriss, C. 1973. Additional spontaneous malesterile mutant in Capsicum annuиm L. Euphytica. 22:527-529.

Shifriss, C. 1995. Male sterility in Capsicum. Capsicum and Eggplant Nswl. 14:11-25.

Shifriss, C. 1997. Male sterility in pepper (Capsicum annuum L.). Euphytica. 93:83-88.

Shifriss, C. and S. Cohen. 1987. A progress in breeding for resistance to $\mathrm{CMV}$ in pepper. Capsicum Nswl. 6:60.

Shifriss, C. and E. Eidelman. 1987. Inheritance studies with nine characters in Capsicum annuum L. Euphytica. 36:873-875.

Shifriss, C. and R. Frankel. 1969. A new male sterility gene in Capsicum annuиm L. J. Amer. Soc. Hort. Sci. 94:385-387.

Shifriss, C. and Y. Hakim. 1977. Segregation for prebifurcation shooting, stem length and leaf number of main stem in two crosses of Capsicum annuum L. Euphytica. 26:491-495.

Shifriss, C. and M. Pilovsky. 1992. Studies of the inheritance of mature fruit color in Capsicum annuum L. Euphytica. 60:123-126.

Shifriss, C., M. Pilovsky, and J.M. Zack. 1992. Resistance to Leveillula mildew (Oidiopsis taurica) in Capsicum annuum L. Proc. 8th Eucarpia Meeting Genetics and Breeding on Capsicum and Eggplant, Rome, Italy. 7-10 Sept. 1992. 172-177.

Shifriss, C. and I. Rylski. 1972. A male sterile (ms-2) gene in 'California Wonder' pepper (C. annuum). HortScience. 7:36.

Shuh, D.M. and J.F. Fontenot. 1990. Gene transfer of multiple flowers and pubescent leaf from Capsicum chinense into Capsicum annuum backgrounds. J. Am. Soc. Hort. Sci. 115:499502.

Singh, J., and M.R. Thakur. 1977. Genetics of resistance to tobacco mosaic virus, cucumber mosaic virus and leaf curl virus in hot pepper (Capsicum annuum). Proc. 3rd Eucarpia meeting on Capsicum Working Group, Montfavet, Avignon, France. 5-8 July 1977. 119-126.

Smith, P.G. 1950. Inheritance of brown and green mature color in peppers. J. Hered. 41:138-140.

Smith, P.G. 1951. Deciduous ripe fruit character in peppers. Proc. Amer. Soc. Hort. Sci. 57:343344.

Souza-Sobrinho, F., W.R. Maluf, L.A.A. Gomes, and V.C. Campos. 2002. Inheritance of resistance to Meloidogyne incognita race 2 in the hot pepper cultivar Carolina Cayenne (Capsicum annuum L.). Genet. Mol. Res. 1:271-279.

Stewart, C., B.C. Kang, K. Liu, M. Mazourek, S.L. Moore, E.Y. Yoo, B.D. Kim, I. Paran, and M.M. Jahn. 2005. The Pun1 gene for pungency in pepper encodes a putative acyltransferase. Plant J. 42:675-688.

Subramanya, R. and H.Y. Ozaki. 1984. Inheritance of closed flower in pepper. Euphytica. 33:1316.

Sy, O., P.W. Bosland, and R. Steiner. 2005. Inheritance of Phytophthora stem blight resistance as compared to Phytophthora root rot and Phytophthora foliar blight resistance in Capsicum annuит L. J. Amer. Soc. Hort. Sci. 130:75-78.

Szarka, J., and G. Csillery. 1995. Defence systems against Xanthomonas campestris pv. vesicatoria in pepper. Proc. 9th Eucarpia Meeting on Genetics and Breeding of Capsicum and Eggplant, Budapest, Hungary. 21-25 Aug., 1995. 184-187.

Tai, T.H., D. Dahlbeck, E.T. Clark, P. Gajiwala, R. Pasion, M.C. Whalen, R.E. Stall, and B.J.
Staskawicz. 1999a. Expression of the Bs2 pepper gene confers resistance to bacterial spot disease in tomato. Proc. Natl. Acad. Sci. USA. 96:14153-14158.

Tai, T., D. Dahlbeck, R.E. Stall, J. Peleman, and B.J. Staskawicz. 1999b. High-resolution genetic and physical mapping of the region containing the $B s 2$ resistance gene of pepper. Theor. Appl. Genet. 99:1201-1206.

Thabuis, A., A. Palloix, S. Pflieger, A.M. Daubèze, C. Caranta, and V. Lefebvre. 2003. Comparative mapping of Phytophthora resistance loci in pepper germplasm: Evidence for conserved resistance loci across Solanaceae and for a large genetic diversity. Theor. Appl. Genet. 106:1473-1485.

Thies, J.A. 2004. IFAFS final report.

Theis, J.A. and R.L. Fery. 1998. Modified expression of the $N$ gene for southern root-knot nematode resistance in pepper at high soil temperatures. J. Amer. Soc. Hort. Sci. 123:1012-1015.

Thies, J.A. and R.L. Fery. 2002. Heat stability of resistance to southern root-knot nematode in bell pepper genotypes homozygous and heterozygous for the $N$ gene. J. Amer. Soc. Hort. Sci. 127:371-375.

Thorup, T.A., B. Tanyolac, K.D. Livingstone, S. Popovsky, I. Paran, and M. Jahn. 2000. Candidate gene analysis of organ pigmentation loci in the Solanaceae. Proc. Natl. Acad. Sci. USA. 97:11192-11197.

Todorov, J. 1992. Inheritance of the height of red pepper plants for grinding. Proc. 8th Meeting on Genetics and Breeding on Capsicum and Eggplant, Rome. Italy. 7-10 Sept., 1992. 96-99.

Uzo, J.O. 1984. Hybrid vigor and gene action of two qualitative traits of flavor peppers in Nigeria. Scientia Horticulturae 22:321-326.

van den Berkmortel, L.G. 1977. Breeding pepper for resistance to a strain of TMV. Proc. 3rd Eucarpia Meeting on Genetics and Breeding of Capsicum and Eggplant, 5-8 July 1977. Avignon-Montfavet, France. 89-92.

Van der Beek, J.G. and A. Ltifi. 1990. Variation in fasciculation in $\mathrm{F}_{4}$ populations of pepper. Capsicum Eggplant Nswl. 8/9:34-35.

Voorrips, R.E., R. Finkers, L. Sanjaya, and R. Droenwold. 2004. QTL mapping of anthracnose (Colletotrichum spp.) resistance in a cross between Capsicum annuum and C. chinense. Theor. Appl. Genet. 109:1275-1282.

Votava, E.J., C. Balok, D. Coon, and P.W. Bosland. 2000. Inheritance of unique fruit and foliage colour mutation in NuMex Pinata. J. Hered. 91:60-61.

Votava, E.J. and P.W. Bosland. 2002. Novel sources of non-pungency in Capsicum species. Capsicum Eggplant Nswl. 21:66-68.

Walker, S.J. and P.W. Bosland. 1999. Inheritance of Phytophthora root rot and foliar blight resistance in pepper. J. Amer. Soc. Hort. Sci. 124:14-18.

Wang, H., D. Wang, and Y. Li. 2003. Advances in the heterosis breeding using the CMS lines. J. Guangdong Agri. Sci. 5:16-18. [in Chinese].

Wang, D., M. Wang, Y. Wang, and Y. Yan. 1995. Advances in the inheritance of and breeding for resistance to Phytophthora blight. China Veg. 3:50-53. [in Chinese].

Wang, D., M. Wang, Y. Wang, and Y. Yan. 1996. Advances in hot pepper breeding for resistance to cucumber mosaic virus (CMV). China Veg. 1:51-55. [in Chinese].

Wolff, D.W., W.W. Collins, and T.J. Monaco. 1992. Inheritance of tolerance to the herbicide bentazon in peppers (Capsicum annuиm L.). J. Amer. Soc. Hort. Sci. 117:985-990. 
Yang, S. 1981. Breeding of male sterile lines in hot pepper. Acta Horticulturae Sinica. 8:49. [in Chinese].

Yang, T. and H. Park. 1998. The study on inheritance of several characters in Capsicum annuиm L. RDA J. Hort. Sci. 40:1-8.

Yang, F., S. Yang, E. Jiang, Z. Wang, and J. Li. 1994. Breeding and application of male sterile line 'AB92' in bell pepper. J. Liaoning Agr. Sci. 6:15-18. [in Chinese].

Yazawa, S., T. Sato, and T. Namiki. 1991. Interspecific hybrid dwarfism and geographical distribution of the dwarfness gene in Capsicum. J. Jpn. Soc. Hort. Sci. 58:609-618.
Yeam, I., B.C. Kang, W. Lindeman, J.D. Frantz, N. Faber, and M.M. Jahn. 2005. Allele-specific CAPS markers based on point mutations in resistance alleles at the pvrl locus encoding eIF4E in Capsicum. Theor. Appl. Genet. 112:178-186.

Yuan, J. and S. Li. 2000. Study of floral organ morphology and inheritance of a new functional male sterile pepper line. Hereditas (Beijing). 22:28-30. [in Chinese].

Zatyko, L., and A. Moor. 1998. Linkage between an $a l$ gene (anthocyanin less) and the $L^{3}$ gene of TMV resistance in pepper. Proc. 10th Eucarpia Meeting on Genetics and Breeding of Capsi- cum and Eggplant, Avignon, France. 7-11 Sept. 1998. 249.

Zewdie, Y. and P.W. Bosland. 2001. Allelic test for closed flower trait in Capsicum. Capsicum Eggplant Nswl. 20:58-59.

Zhang, B., S. Huang, G. Yang, and J. Guo. 2000. Two RAPD markers linked to major fertility restorer gene in pepper (Capsicum annuum L.). Euphytica. 113:155-161.

Zitter, T.A. 1972. Naturally occurring pepper virus strains in south Florida. Plant Dis. Reptr. 56:586-590.

Zitter, T.A. and A.A. Cook. 1973. Inheritance of tolerance to a pepper virus in Florida. Phytopathology. 63:1211-1212. 